\title{
A quantitative comparison of dispersed spore/pollen and plant megafossil assemblages from a Middle Jurassic plant bed from Yorkshire, UK
}

\author{
Sam M. Slater and Charles H. Wellman
}

\begin{abstract}
Detailed quantitative data has previously been collected from plant megafossil assemblages from a Middle Jurassic (Aalenian) plant bed from Hasty Bank, North Yorkshire, UK. We conducted a similar analysis of palynological dispersed sporomorph (spore and pollen) assemblages collected from the same section using the same sampling regime: 67 sporomorph taxa were recorded from 50 samples taken at $10 \mathrm{~cm}$ intervals through the plant bed. Basic palynofacies analysis was also undertaken on each sample. Both dispersed sporomorph and plant megafossil assemblages display consistent changes in composition, diversity (richness), and abundance through time. However, the dispersed sporomorph and plant megafossil records provide conflicting evidence for the nature of parent vegetation. Specifically, conifers and ferns are underrepresented in plant megafossil assemblages, bryophytes and lycopsids are represented only in sporomorph assemblages, and sphenophytes, pteridosperms, Caytoniales, Cycadales, Ginkgoales and Bennettitales are comparatively underrepresented in sporomorph assemblages. Combined multivariate analysis (correspondence analysis and nonmetric multidimensional scaling) of sporomorph occurrence/abundance data demonstrates that temporal variation in sporomorph assemblages is the result of depositional change through the plant bed. The reproductive strategies of parent plants are considered to be a principal factor in shaping many of the major abundance and diversity irregularities between dispersed sporomorph and plant megafossil data sets that seemingly reflects different parent vegetation. Preferential occurrence/preservation of sporomorphs and equivalent parent plants is a consequence of a complex array of biological, ecological, geographical, taphonomic, and depositional factors that act inconsistently between and within fossil assemblages, which results in notable discrepancies between data sets.
\end{abstract}

Sam M. Slater and Charles H. Wellman. Department of Animal and Plant Sciences, University of Sheffield, Alfred Denny Building, Western Bank, Sheffield, S10 2TN, United Kingdom. E-mail: samslater444@gmail. com

Accepted: 3 June 2015

Published online: 14 October 2015

Supplemental materials deposited at Dryad: doi:10.5061/dryad.tg469

\section{Introduction}

Understanding the causes of temporal variation in paleofloras is a fundamental objective of paleobotany. Extracting these causes is, however, frequently problematic as it is often difficult to determine the dominant controls on the constituents of fossil assemblages. Such controls include ecological, climatic, depositional, and preservational factors. Establishing the causes of paleofloristic temporal variation is clearly enhanced when a multidisciplinary approach is used, as the overreliance on singular lines of evidence can often lead to over interpretation. Comparing data from the plant megafossil and terrestrial palynological records can provide important insight into ecological and preservational biases that can shape diversity (richness) and abundance patterns of these fossil assemblages. Thus, such comparisons can help to determine the reliability of paleofloristic interpretations based on the spore and pollen (sporomorph) and plant megafossil records in isolation.

The sequences of North Yorkshire, UK offer a rare example of extensive Middle Jurassic terrestrial deposits. The sedimentary successions have previously been studied in detail for their paleontological significance (e.g., Romano and Whyte 2003) and particularly for the famous plant beds that are scattered throughout these sequences (e.g., Black 1929; van Konijnenburgvan Cittert 1968, 1975, 1996, 2008; Crane and Herendeen 2009; Spicer and Hill 1979; van Konijnenburg-van Cittert and Morgans 1999). Although plant megafossil studies from these 
deposits are common in the literature (e.g., Harris 1941, 1944, 1952, 1953, 1961a,b, 1964, 1969, 1978, 1979; van Konijnenburg-van Cittert 1972, 1975, 1978, 1981, 1989, 1996, 2008; Harris et al. 1974; Spicer and Hill 1979; Hill 1990; Morgans 1999; van Konijnenburg-van Cittert and Morgans 1999), published dispersed spore and pollen investigations remain comparatively sparse (e.g., Couper 1958; Chaloner 1968; Chaloner and Muir 1968; Riding 1984; Riding and Wright 1989; Gowland and Riding 1991; Boulter and Windle 1993; Hubbard and Boulter 1997; Butler et al. 2005; Srivastava 2011).

This study provides a detailed palynological assessment of a plant bed from Hasty Bank, North Yorkshire, UK that was previously analyzed for its plant megafossil contents. Spicer and Hill (1979) carried out a comprehensive quantitative study of this plant bed in which they sampled contiguous plant megafossil census counts through a through a $5 \mathrm{~m}$ outcrop section. Plant megafossil counts were carried out on rock blocks of either 50 or $25 \mathrm{~cm}^{2}$ parallel to bedding and 10 or $20 \mathrm{~cm}$ in depth, perpendicular to bedding. Counts were then multiplied accordingly so that all abundances correspond to a $50 \times 50 \times 20 \mathrm{~cm}^{3}$ block of sediment. The histogram of their results is provided in Supplementary Figure 1. Sporomorph quantitative data was analyzed here from the same section discussed in Spicer and Hill (1979) in order to compare this with the quantitative plant megafossil data. Palynofacies analysis was also carried out in order to aid environmental reconstructions (Tyson 1995). Paleofloristic comparisons of sporomorph and plant megafossil data are possible due to comprehensive in situ spore/pollen (e.g., van Konijnenburg-van Cittert 1968, 1971, 1978, 1981, 1989, 1993, 2000; Pedersen et al. 1989; Hill 1990; Osborn and Taylor 1993; Balme 1995; Friis and Pedersen 1996; Yang et al. 2008) and ultrastructural transmission electron microscope (TEM) studies (e.g., Batten and Dutta 1997) which means that the majority of Middle Jurassic sporomorphs can now be assigned at least to family level plant classification.

By comparing dispersed spore/pollen assemblages with plant megafossil data in association with palynofacies analysis it was anticipated that a more realistic paleofloristic and paleoenvironmental interpretation would be possible and potential discrepancies in data sets would help to explain preservational biases between sporomorph and plant megafossil records. Since sporomorph and plant megafossil assemblages undergo different transportation and depositional processes, it was expected that the respective fossil assemblages would be notably dissimilar in composition (e.g., Bercovici et al. 2008, 2009), with the anticipation that our analyses may shed light on the reasons behind these differences.

\section{Geological Setting}

The Mesozoic sequences of the Cleveland Basin, northeast England (Fig. 1) have been intensively studied since the early nineteenth century (e.g., Young and Bird 1822) and offer important insight into both terrestrial and marine environments of this time. Middle Jurassic sediments of the Cleveland Basin are dominated by the chiefly terrestrial sequences of the Ravenscar Group (Fig. 2). Regional uplift and associated relative sea level fall led to the deposition of extensive fluviodeltaic sequences derived from upland areas surrounding the Cleveland Basin. Marine beds occur sporadically throughout the Ravenscar Group as a result of marine incursions from the south and east (Hemingway and Knox 1973; Knox 1973; Hemingway 1974; Nami and Leeder 1978; Leeder and Nami 1979; Hancock and Fisher 1981;

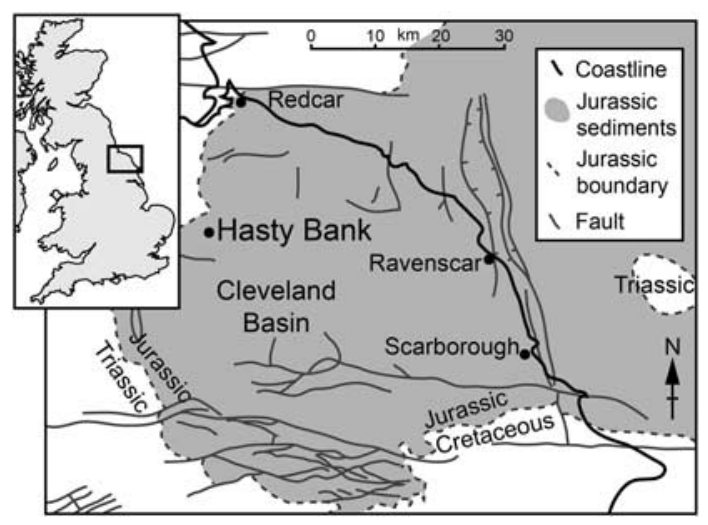

FIGURE 1. Location and geological setting of Hasty Bank, northeast England. Modified from Milsom and Rawson (1989); Mjøs and Prestholm (1993); Cox and Sumbler (2002); Palliani and Riding (2000); Slater et al. (2015). 
Livera and Leeder 1981; Fisher and Hancock 1985; Kantorowicz 1985; Alexander 1989, 1992; Riding and Wright 1989; Gowland and Riding 1991; Rawson and Wright 2000; Powell 2010). The Ravenscar Group provides an exceptional example of extensive Middle Jurassic terrestrial sequences and the plethora of plant fossils

\begin{tabular}{|c|c|c|c|c|c|}
\hline Epoch & Stage & \multicolumn{3}{|c|}{ Lithostratigraphical Division } & $\begin{array}{l}\text { Age } \\
(\mathrm{Ma})\end{array}$ \\
\hline \multirow{8}{*}{ 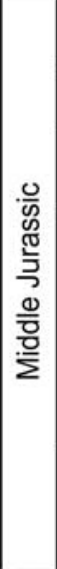 } & $\begin{array}{l}\text { Lower } \\
\text { Callovian }\end{array}$ & \multicolumn{3}{|c|}{ Cornbrash Formation (25 m) } & \\
\hline & Bathonian & \multirow{3}{*}{$\begin{array}{l}\text { Eે } \\
\text { ᄋ } \\
\text { ㄱ. }\end{array}$} & \multirow{2}{*}{$\begin{array}{l}\text { Scalby } \\
\text { Formation } \\
(60 \mathrm{~m})\end{array}$} & $\begin{array}{c}\text { Long Nab } \\
\text { Member }(45 \mathrm{~m})\end{array}$ & \\
\hline & $\begin{array}{c}\text { Upper } \\
\text { Bajocian }\end{array}$ & & & $\begin{array}{c}\text { Moor Grit } \\
\text { Member }(15 \mathrm{~m})\end{array}$ & \\
\hline & & & \multicolumn{3}{|c|}{ Scarborough Formation $(30 \mathrm{~m})$} \\
\hline & $\begin{array}{c}\text { Lower } \\
\text { Bajocian }\end{array}$ & \multirow[t]{3}{*}{ 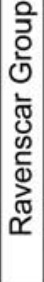 } & $\begin{array}{l}\text { Cloughton } \\
\text { Formation } \\
\text { (85 m) }\end{array}$ & $\begin{array}{c}\text { Gristhorpe } \\
\text { Member }(26 \mathrm{~m}) \\
\begin{array}{c}\text { Lebberston } \\
\text { Member }(9 \mathrm{~m}) \\
\text { Sycarham } \\
\text { Member }(50 \mathrm{~m})\end{array}\end{array}$ & \\
\hline & & & \multicolumn{2}{|c|}{ Eller Beck Formation (4 m) } & \\
\hline & Aalenian & & \multicolumn{2}{|c|}{ Saltwick Formation (40 m) } & \\
\hline & & \multicolumn{3}{|c|}{ Dogger Formation (2 m) } & \\
\hline
\end{tabular}

FIGURE 2. Subdivision of Middle Jurassic sequences of the North Yorkshire Coast. Marine units shaded. The arrow indicates the stratigraphic position of the plant bed. Modified from Rawson and Wright (2000); Slater et al. (2015). (e.g., van Konijnenburg-van Cittert and Morgans 1999) and dinosaur footprints (Whyte and Romano 1993, 2001a,b; Romano et al. 1999; Romano and Whyte 2003; Whyte et al. 2006, 2007, 2010) make the Cleveland Basin an important region for paleontology.

The plant bed under investigation is located on the northern slope of Hasty Bank (NZ 567 037), situated within the northwest region of the North York Moors National Park, northeast England. The plant bed occurs at the base of the Aalenian Saltwick Formation, stratigraphically located at the base of the Ravenscar Group (Fig. 2) and lies unconformably above the marine Dogger Formation. The bed is approximately $7 \mathrm{~m}$ thick and has previously yielded a varied flora of 90 species (Hill and van Konijnenburg-van Cittert 1973; Hill 1974; Spicer and Hill 1979). Two lithologies dominate the plant bed (Fig. 3), a claystone that forms the lower part of the section and a siltstone that occupies the majority of the upper part of the section. An erosional surface is present between the claystone and the siltstone. A thin lens of dark gray clay is also present at the top of the section (Hill and van Konijnenburg-van Cittert 1973; Hill 1974).

The claystone is uniform dark gray in color. Grain size is homogeneous through the unit and

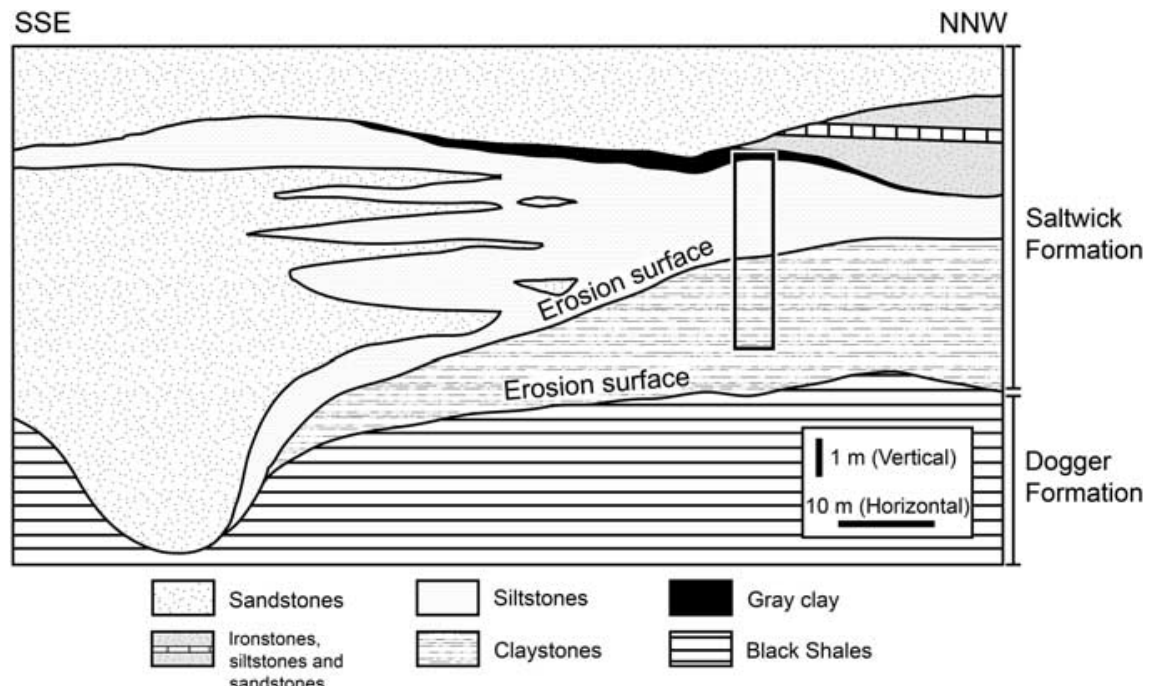

FIGURE 3. Cross section of the geology of the main plant bed at Hasty Bank. Vertical and horizontal scales provided (vertical scale exaggerated four times). The section discussed is shown by the rectangle. Adapted from Hill and van Konijnenburg-van Cittert (1973); Spicer and Hill (1979); van Konijnenburg-van Cittert and Morgans (1999). 
thin (1-3 mm scale) horizontal laminae are abundant. The rock is relatively soft and breaks apart easily along laminae, which often reveal highly abundant fragmentary plant megafossils.

The siltstone is a homogeneous medium gray color. Grain size is uniform through the unit and larger, more prominent horizontal laminae (5-10 mm scale) are present. The rock is harder than the claystone and fragmentary plant megafossils are abundant, although less so than in the claystone. Horizontal roots occur in low abundance within the basal $1 \mathrm{~m}$ of the siltstone, these are typically less than $2 \mathrm{~cm}$ in length and $\sim 2 \mathrm{~mm}$ in width.

The gray clay at the top of the section is a homogeneous very dark gray color. Grain size is uniform through the unit and no sedimentary structures are visible. The rock is very soft and not fully lithified. Plant megafossils are less common in the gray clay than in the claystone and siltstone.

Previous Interpretations of the Depositional Environments at Hasty Bank.-The Hasty Bank plant bed was first recognized as an important fossil locality by Black (1929). Subsequent paleobotanical and paleoecological studies have commented on possible environments of deposition for the plant bed, most notably by Harris (1964), Hill and van Konijnenburg-van Cittert (1973), Hill (1974), and van Konijnenburgvan Cittert and Morgans (1999).

Harris (1964) postulated that the claystone at the base of the plant bed (Fig. 3) was deposited in a coastal environment periodically flooded by seawater. These interpretations were based on the occurrence of the pteridosperm Pachypteris papillosa in association with rare marine microfossils thought to be derived from marine flooding events. Harris (1983) reconstructed $P$. papillosa as a large shrub that formed mangrove-like thickets along tidal rivers. Spicer and Hill (1979) showed that P. papillosa is markedly more abundant within the claystone deposit compared to the rest of the section.

The siltstone is interpreted as the peripheral fringes of a large channel sandstone deposit immediately adjacent to the southeast of the plant bed (Fig. 3). Hill and van Konijnenburgvan Cittert (1973) concluded that the siltstone was deposited in the slower flowing region of the channel. It is possible that the siltstone could however represent a levee or floodplain deposit peripheral to the sandstone. The channel has cut into the underlying sediments forming an erosional surface between the claystone and the siltstone and thus there is a time gap between these deposits.

Previous depositional environmental interpretations for the gray clay are lacking. However, sedimentological, sporomorph and palynofacies evidence from this study suggests that this deposit represents a swamp or an abandoned channel.

\section{Materials and Methods}

Collection.-A total of 50 samples (HB1-HB50, numbered in reverse stratigraphic order, i.e., $\mathrm{HB1}$ is at the top of the section) were collected at $10 \mathrm{~cm}$ vertical intervals from the main Hasty Bank plant bed (NZ 567 037) for palynological processing. Samples were taken from the identical section of that discussed by Spicer and Hill (1979), shown in Figure 3. Christopher R. Hill (of Spicer and Hill [1979]) was present during collection of samples to ensure the exact position of the section was located. Sampling required the excavation of approximately $50 \mathrm{~cm}$ of modern deposits to access the outcrop. The exterior of the outcrop was weathered between 5 and $20 \mathrm{~cm}$ deep into the rock. The section was therefore excavated a further $\sim 30 \mathrm{~cm}$ into the outcrop to ensure fresh exposure. Samples HB1-HB3 are from the gray clay at the top of the section; HB4-HB28 are from the siltstone unit; and HB29-HB50 are from the claystone unit.

Processing.-Dry rock samples were weighed at $20 \mathrm{~g}$ before being dissolved in $40 \%$ hydrochloric acid for at least 24 hours to remove carbonates, followed by two week maceration in $40 \%$ hydrofluoric acid to remove silicates. Samples were agitated every two days to ensure full break down of rock material. Samples were then decanted and fresh water added, repeating the process until neutral. One day was left between decants to ensure minimal loss of palynomorphs. Two Lycopodium tablets (produced by the University of Lund, Sweden; batch 1031) were added before sieving at $10 \mu \mathrm{m}$. Centrifuging residues in zinc chloride was then 
undertaken to remove heavy minerals. Residues were then sieved again at $10 \mu \mathrm{m}$ to remove the heavy liquid and final residues were spread across cover slips and gently heated on a hot plate to remove excess water. Cover slips were then mounted onto slides using epoxy resin on a hot plate. All materials (rock samples and slides) are housed in the collections of the Centre for Palynology at the University of Sheffield.

Counting.-Slides were examined under a Meiji Techno (MA151/35/50) light microscope. A minimum of 200 indigenous Jurassic sporomorphs were counted from each sample in addition to any Lycopodium spores from tablets in order to assess the relative organic richness of samples. The Lycopodium tablets contain a known quantity of spores $(20,848 \pm 1546$ spores per tablet). This allows the palynomorph productivity of each sample to be assessed when counting sporomorphs, as numbers of Lycopodium spores can be compared with numbers of indigenous Jurassic sporomorphs to assess the palynomorph richness of samples. In this study, increased numbers of Lycopodium correspond to a decrease in palynomorph productivity per unit of sediment. Counts were carried out in systematic traverses across slides to ensure no grains were missed. For presence/absence data, the remainder of the slide was then examined in the same fashion to identify species that were not present in the count data. The complete raw data set is provided in Supplementary Table 1. For sporomorph images that refer closely to the taxonomic identifications used in this study, see Couper (1958), Boulter and Windle (1993) and Srivastava (2011).

Palynofacies Analysis. - The term palynofacies typically refers to all of the visible organic particles (usually $2-250 \mu \mathrm{m}$ in size) that occur within palynological maceration residues (Traverse 2007). Palynofacies analysis is commonly used to assess depositional environments (e.g., Parry et al. 1981; Boulter and Riddick 1986; Van der Zwan 1990; Brugman et al. 1994; Oboh-Ikuenobe and Yepes 1997; Oboh-Ikuenobe et al. 2005; Carvalho et al. 2006). In this study, palynofacies analysis attempts to provide a more in depth interpretation of the depositional environments at Hasty Bank. A similar palynofacies classification scheme to Tyson (1995) and Batten and Stead (2005) was used to categorize organic matter. Categories for palynofacies debris are: spores; pollen; algae; dinoflagellate cysts; acritarchs; humic debris; amorphous organic matter (AOM); Botryococcus; structured vitrinite; unstructured vitrinite; cuticle; and inertinite. Counts of 200 palynodebris were carried out on all samples, the complete raw data set is provided in Supplementary Table 2.

Statistical Analysis.-Correspondence analysis (CA) and nonmetric multidimensional scaling (NMDS) were performed on sporomorph data sets to further understand the causes of floral variation through the Hasty Bank plant bed. Correspondence analysis and NMDS are ordination methods that plot complex multivariate data onto a minimal number of axes (e.g., Jardine et al. 2012). Correspondence analysis is an eigenvector method of ordination that produces a graphical representation of a contingency table (Spicer and Hill 1979). Nonmetric multidimensional scaling is a nonparametric ordination technique that uses ranked distances between samples to assess the degree of similarity between samples (Chatfield and Collins 1980; ter Braak 1995; Legendre and Legendre 2012; Hammer and Harper 2006; Jardine et al. 2012), hence clustering of samples in ordination space indicates high compositional similarity between those samples. For comprehensive descriptions of CA and NMDS see Greenacre (2007) and Cox and Cox (2001), respectively. Correspondence analysis and NMDS are becoming increasingly used in palynological analysis of quantitative paleoecological studies (e.g., Kovach 1989, 1993; Wing and Harrington 2001; Hammer and Harper 2006; Bonis and Kürschner 2012; Jardine et al. 2012; Stukins et al. 2013) as such methods allow the user to extract information on the major causes of variation from complex data sets. Correspondence analysis was chosen over detrended correspondence analysis (DCA) as this method was employed by Spicer and Hill (1979) on megafossil data, thus to allow comparison of ordinations we used the same technique here. Furthermore, CA ordinations do not indicate the need for DCA. Both CA and NMDS are used here to assess abundance and presence/absence data. For NMDS ordinations, the Bray-Curtis dissimilarity metric was used 
to generate distances between samples as this method is considered to perform well in ecological analyses (e.g., Minchin 1987; Harrington 2008; Bowman et al. 2014). Repeated runs were carried out for two dimensions until a convergent solution was established. Principal components rotation and centering was then applied to the final ordination. Nonmetric multidimensional scaling ordinations were performed using $\mathrm{R}$, version 3.1.2 ( $\mathrm{R}$ Core Team 2014), within the package "vegan", version 2.2-1 (Oksanen et al. 2015). Sporomorph relative abundances have been transformed logarithmically for CA and NMDS. This procedure condenses the differences in scores between abundant and rare species between samples, thus reducing the impact of highly abundant taxa on the data set and also reducing statistical noise. Spicer and Hill (1979) suggested that the most effective way to assess megafossil data in ordinations was to logarithmically transform abundances. Species that are present in samples but not in counts have been excluded from logarithmically transformed relative abundance ordinations. For taxonomic CA the same data has been used with the exclusion of species that contribute less than $1 \%$ of the total count to eliminate statistical noise. Presence/ absence CA and NMDS were performed to assess co-occurrence and compositional variation between samples. For presence/ absence analyses all species are included; species that are present are scored as 1 , species that absent are scored as 0 . Spiked Lycopodium data has been excluded from all ordinations. The statistical program PAST (Hammer et al. 2001) was used to create CA plots.

\section{Results}

Sporomorph Diversity (Richness) and Abundance Variation.-A total of 67 sporomorph taxa were recognized from 50 samples; the entire taxonomic list with associations between sporomorphs and parent plant groups is provided in Supplementary Table 3. The commonly used Chao2 species richness estimator (Colwell and Coddington 1994) gave a species estimate of 69.94 taxa (standard deviation = 3.36) for the entire data set, which suggests the data set was not severely undersampled. Diversities (richness) using presence/absence data (Fig. 4B) are highest within the claystone; diversity (richness) is slightly lower within the siltstone assemblage and lower again in gray clay samples. This indicates that the claystone was deposited at a time of increased floral diversity and/or claystone samples are capturing more sporomorph taxa due to preservational biases.

Relative abundances of all taxa are displayed graphically in Supplementary Figure 2. Relative abundances of the ten most abundant sporomorph taxa are provided in Figure 4A. Sporomorphs have been grouped into their botanical affinities in Figure 5A to extract information on higher taxonomic level temporal floral variations. Spiked Lycopodium spores exhibit the most prominent abundance variation through the sequence. Abundant spiked Lycopodium in gray clay (HB1-HB3) and siltstone (HB4-HB28) samples indicates that claystone samples (HB29-HB50) preserve far greater numbers of indigenous Jurassic sporomorphs.

Bryophytes (Fig. 5A) are represented by two species and are in low abundance throughout the section. Lycopsids are highly diverse (16 taxa) and abundances are low throughout the plant bed, but slightly higher in the siltstone compared to the claystone and gray clay. Sphenophytes are represented by Calamospora mesozoica and abundances are low and relatively constant throughout the section. Ferns are the most diverse group (23 taxa) and are highly abundant through the plant bed. Abundances increase from the claystone into the siltstone and increase again into the gray clay. Pteridosperms are represented by two species of Alisporites; diversity and abundances are low throughout the section, but slightly higher in the siltstone compared to the claystone and gray clay. Caytoniales are represented by the single species Vitreisporites pallidus; similarly to pteridosperms, abundances are low throughout the section, but slightly higher in the siltstone compared to the claystone and gray clay. Conifers constitute the most abundant group and are highly diverse (14 taxa). Abundances decrease markedly from the claystone into the siltstone and decrease again within the gray clay. Relative abundance variation within the conifers is 
most apparent within the three most abundant species: Classopollis torosus, Perinopollenites elatoides, and Araucariacites australis (Fig. 4A). Classopollis torosus and P. elatoides are considerably more abundant within claystone samples, whereas $A$. australis contrasts the overall abundance pattern of the conifers and is more abundant within siltstone samples. Cycadopsida/Ginkgopsida pollen is moderately diverse (four taxa) and displays little change in abundance (Fig. 5A) through the plant bed. Chasmatosporites hians exhibits the most pronounced abundance variation within the Cycadopsida/Ginkgopsida group; C. hians is relatively common in the claystone, but becomes increasingly rare within siltstone samples and is absent above sample HB19. Bennettitales are low in abundance and diversity throughout the plant bed (two taxa). The largest relative abundance variation within the Bennettitales is displayed by Cycadopites carpentieri, which occurs frequently in the basal and upper samples of the section, but is absent from samples HB26 to HB16.

Sporomorph Sample Ordination.-CA and NMDS (Fig. 6) reveal samples from claystone, siltstone, and gray clay units are well separated in ordination space, with only minimal overlap. This illustrates that lithology and apparent floristic composition are correlated and perhaps both are responding to the same principal factors of deposition and/or environment. Logarithmically transformed relative abundance (Figs. 6A,C) and presence/ absence sample multivariate plots (Figs. 6B,D) demonstrate little clustering of stratigraphically adjacent samples within lithological point clouds, suggesting little temporal floral change and habitat partitioning within each of the three depositional settings. For logarithmically transformed relative abundance CA (Fig. 6A) the variance is $14 \%$ for axis one and $9 \%$ for axis two. For presence/absence CA (Fig. 6B) the variance is $11 \%$ for axis one and $8 \%$ for axis two. Gray clay samples display

A

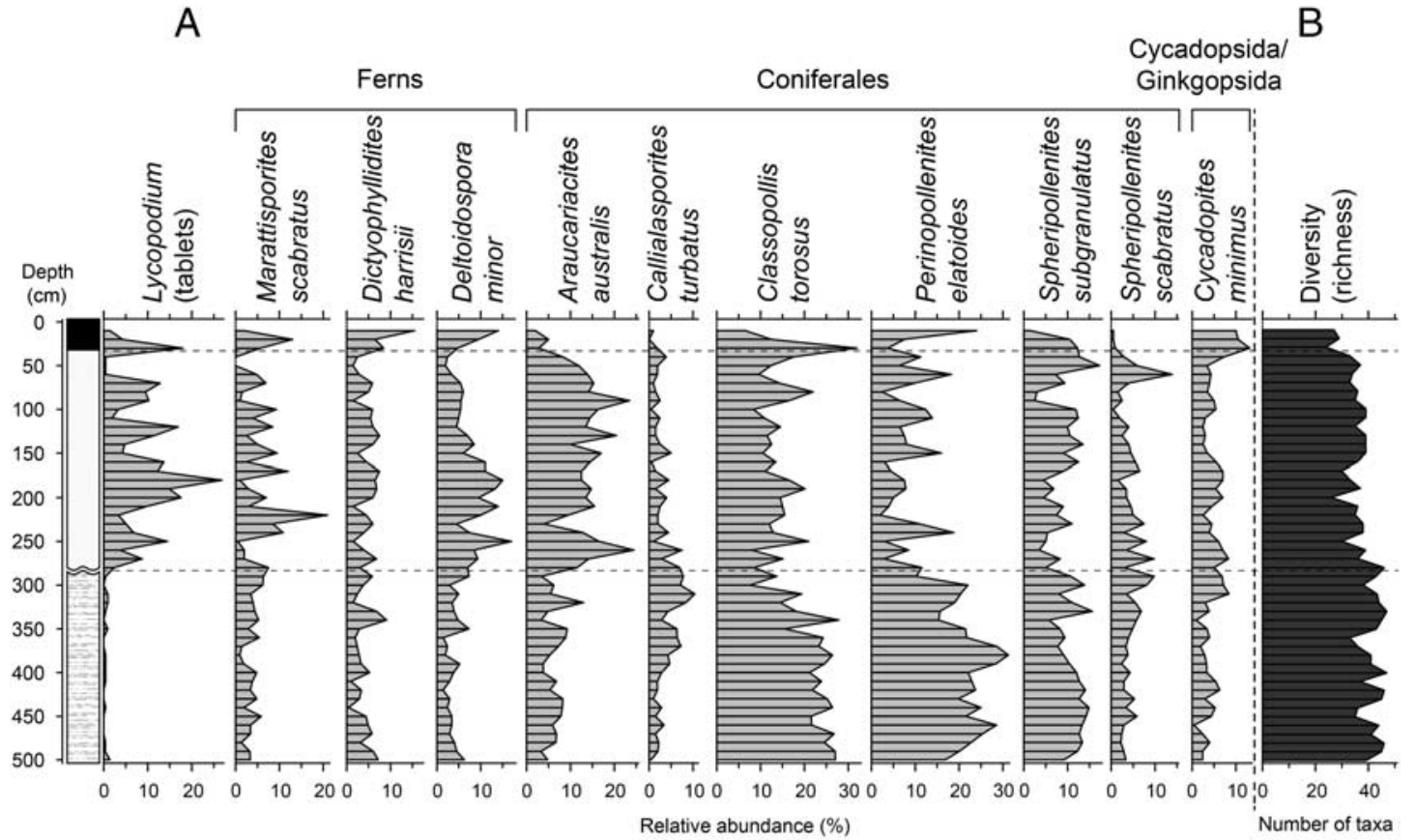

Claystone

Siltstone

Gray Clay

FIGURE 4. A, Relative abundance chart of the ten most abundant sporomorph taxa in addition to spiked Lycopodium. Relative abundances of Jurassic taxa are calculated from counts of at least 200 grains. Spiked Lycopodium count data is shown as a percentage of the indigenous Jurassic taxa plus the spiked Lycopodium itself. B, Sporomorph diversity (richness) for all samples. 


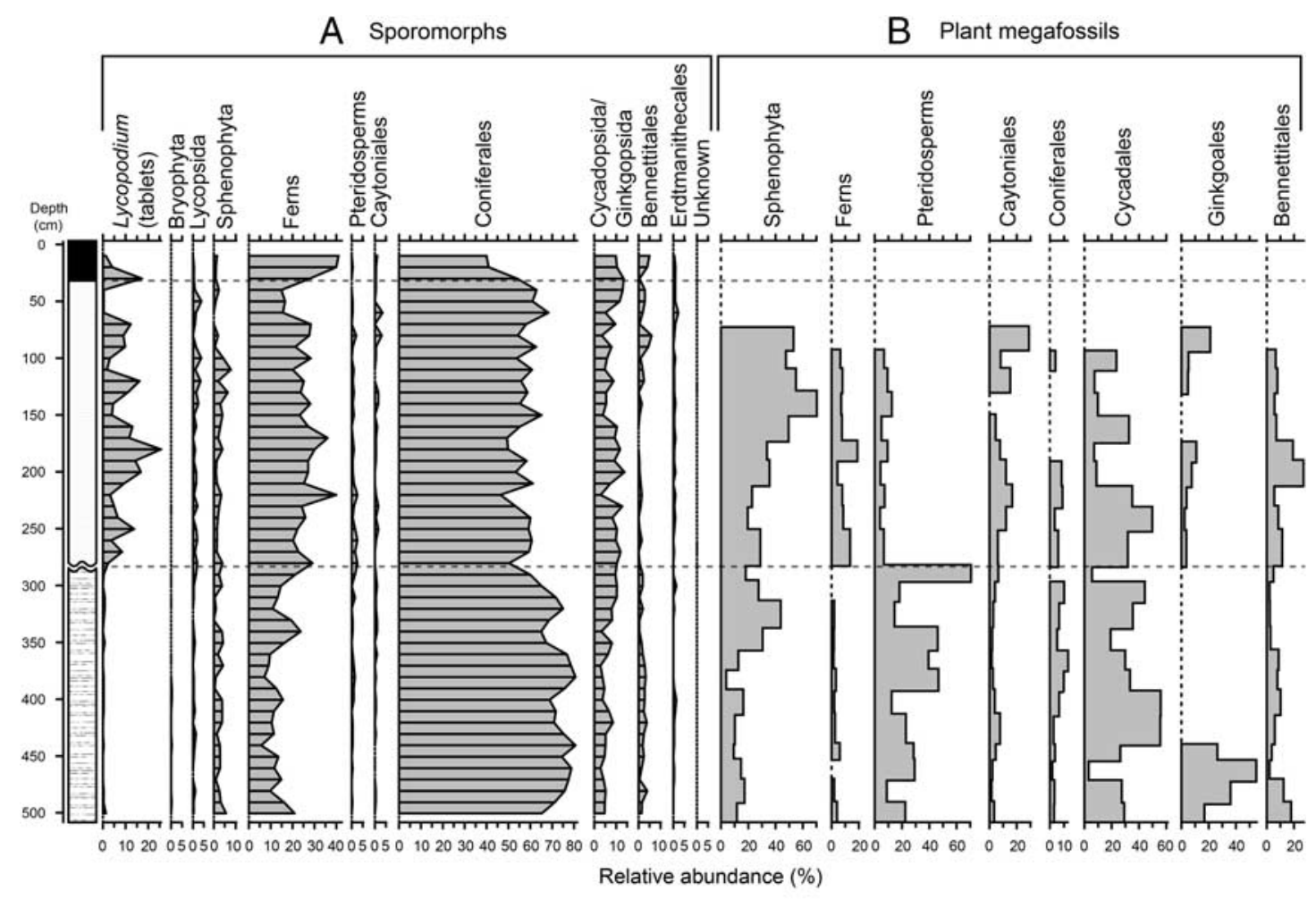

Claystone

Siltstone

Gray Clay

FIGURE 5. Relative abundance charts of (A) sporomorphs and (B) plant megafossils (Spicer and Hill 1979) grouped into their respective botanical affinities. Relative abundances of Jurassic sporomorph taxa are calculated from counts of at least 200 grains. Spiked Lycopodium count data is shown as a percentage of the indigenous Jurassic taxa plus the spiked Lycopodium itself.

some volatility between relative abundance and presence/absence CA (Figs. 6A,B), which potentially reflects the comparatively low abundance of conifers and low overall diversities within the gray clay. However, in all ordinations (Fig. 6) gray clay samples are consistently more similar to siltstone samples than claystone samples. In NMDS ordinations (Figs. 6C,D) samples of different lithologies are separated predominantly on axis one, suggesting this corresponds to depositional setting. Data for Figure 6 is provided in Supplementary Tables 4-7.

Taxon Correspondence Analysis.-The scatter plot of the first two CA axes (43\% cumulative variation) of logarithmically transformed relative abundances of taxa reveals four groupings, labeled A-D (Fig. 7A). Eigenvalues and percentage variance data for Figure 7 is provided in Supplementary Table 8. Relative abundances of taxa from clusters A-D have been grouped and plotted in Figure 7B.
Cluster A (Fig. 7A) is occupied by P. elatoides (Taxodiaceae [van Konijnenburg-van Cittert and van der Burgh 1989; Boulter and Windle 1993; Balme 1995; Couper 1958; Mander et al. 2010; Mander 2011]), Callialasporites turbatus (Araucariaceae [Boulter and Windle 1993]), C. torosus (Cheirolepidiaceae [Harris 1979; Boulter and Windle 1993; Balme 1995; Couper 1958; Ziaja 2006; Mander et al. 2010; Mander 2011]), Spheripollenites subgranulatus (Taxodiaceae [Couper 1958; Boulter and Windle 1993]), and Spheripollenites scabratus (Taxodiaceae [Couper 1958; Boulter and Windle 1993]). Taxa from cluster A are considerably more abundant within claystone samples (Fig. 7B). Cluster B (Fig. 7A) is occupied by C. mesozoica (Sphenophyta [Harris 1978; Boulter and Windle 1993; Balme 1995]), Dictyophyllidites harrisii (Dipteridaceae/Matoniaceae [Couper 1958; Boulter and Windle 1993; van Konijnenburg-van Cittert 1993; Guignard et al. 2009]), and 

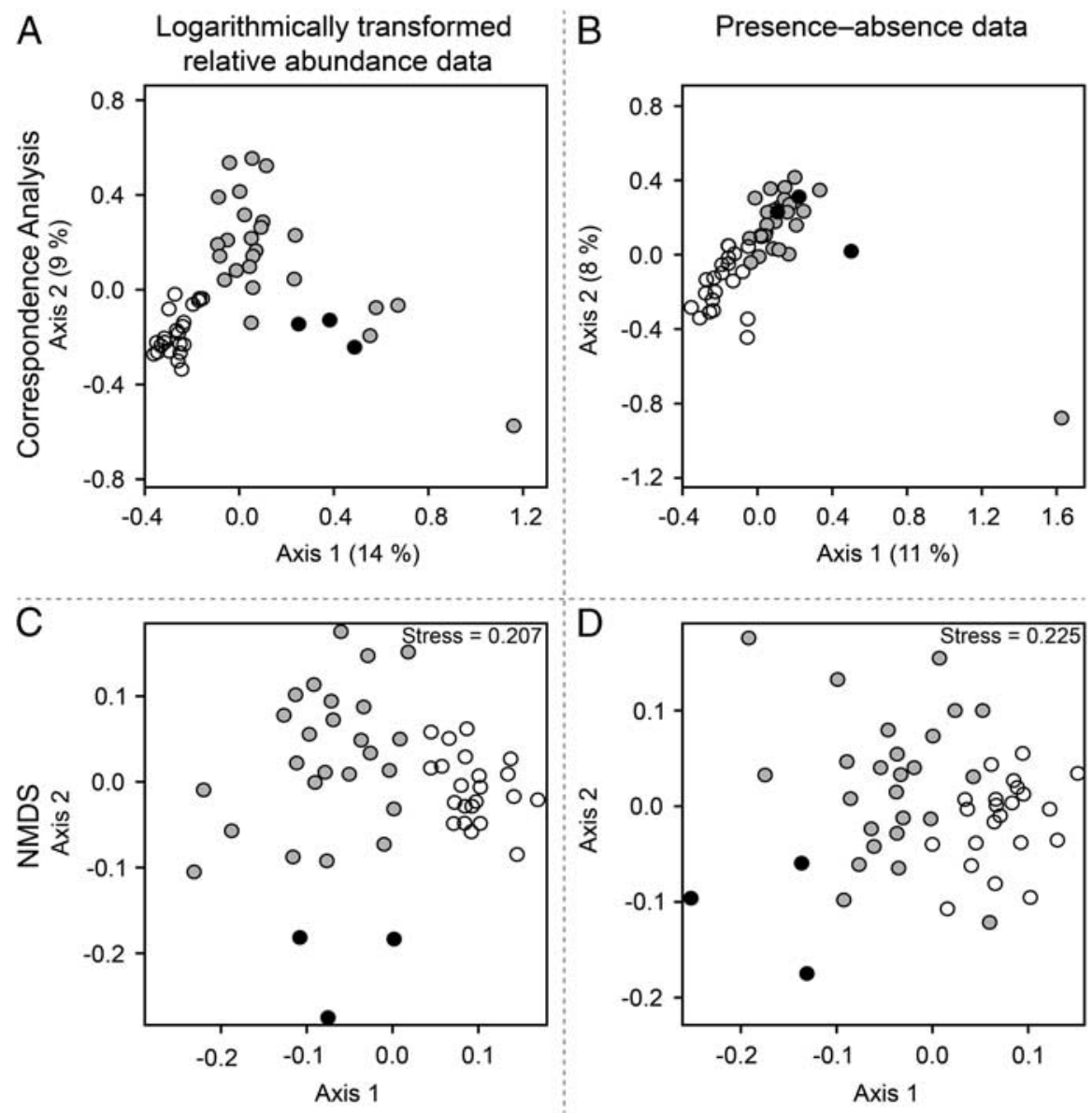

FIGURE 6. Combined ordination plots of samples (spiked Lycopodium excluded). A, B, correspondence analysis; C, D, nonmetric multidimensional scaling. A, C, logarithmically transformed relative abundance data; B, D, presence/absence data. White circles represent claystone samples; gray circles represent siltstone samples; black circles represent gray clay samples.

Marattisporites scabratus (Marattiaceae [Couper 1958; Filatoff 1975; Boulter and Windle 1993; Balme 1995]). Taxa from cluster B display little change in relative abundances through the section (Fig. 7B). Cluster C (Fig. 7A) is occupied by A. australis (Araucariaceae [Couper 1958; Boulter and Windle 1993; Balme 1995; Mander et al. 2010; Mander 2011; Bonis and Kürschner 2012]), Pityosporites microalatus (Pinaceae [Couper 1958; Boulter and Windle 1993]), Cerebropollenites mesozoicus (Coniferales [van Konijnenburg-van Cittert and van der Burgh 1989; Boulter and Windle 1993; Balme 1995]), Cycadopites minimus (Cycadales/Ginkgoales [Boulter and Windle 1993; Balme 1995; Mander et al. 2010]), and Deltoidospora minor (Cyatheaceae/Dicksoniaceae/Dipteridaceae/Matoniaceae [Couper 1958; Boulter and Windle 1993; van Konijnenburg-van
Cittert 1993; Guignard et al. 2009]). Taxa from cluster $\mathrm{C}$ are considerably more abundant within siltstone and gray clay samples (Fig. 7B). Cluster D is occupied by Chasmatosporites apertus (?Cycadales/?Ginkgoales/?Gnetales [Boulter and Windle 1993; Balme 1995]) and Dictyophyllidites equiexinus (Dipteridaceae/ Matoniaceae [Boulter and Windle 1993; van Konijnenburg-van Cittert 1993]). Taxa from cluster D are more abundant within siltstone samples compared to claystone and gray clay samples (Fig. 7B). Cycadopites carpentieri (Bennettitales [Boulter and Windle 1993]) plots separately in ordination space from clusters A-D. Figure 7B demonstrates that C. carpentieri is considerably more abundant within claystone samples. Relative abundances of clusters (Fig. 7B) reveal each point cloud (Fig. 7A) has a 

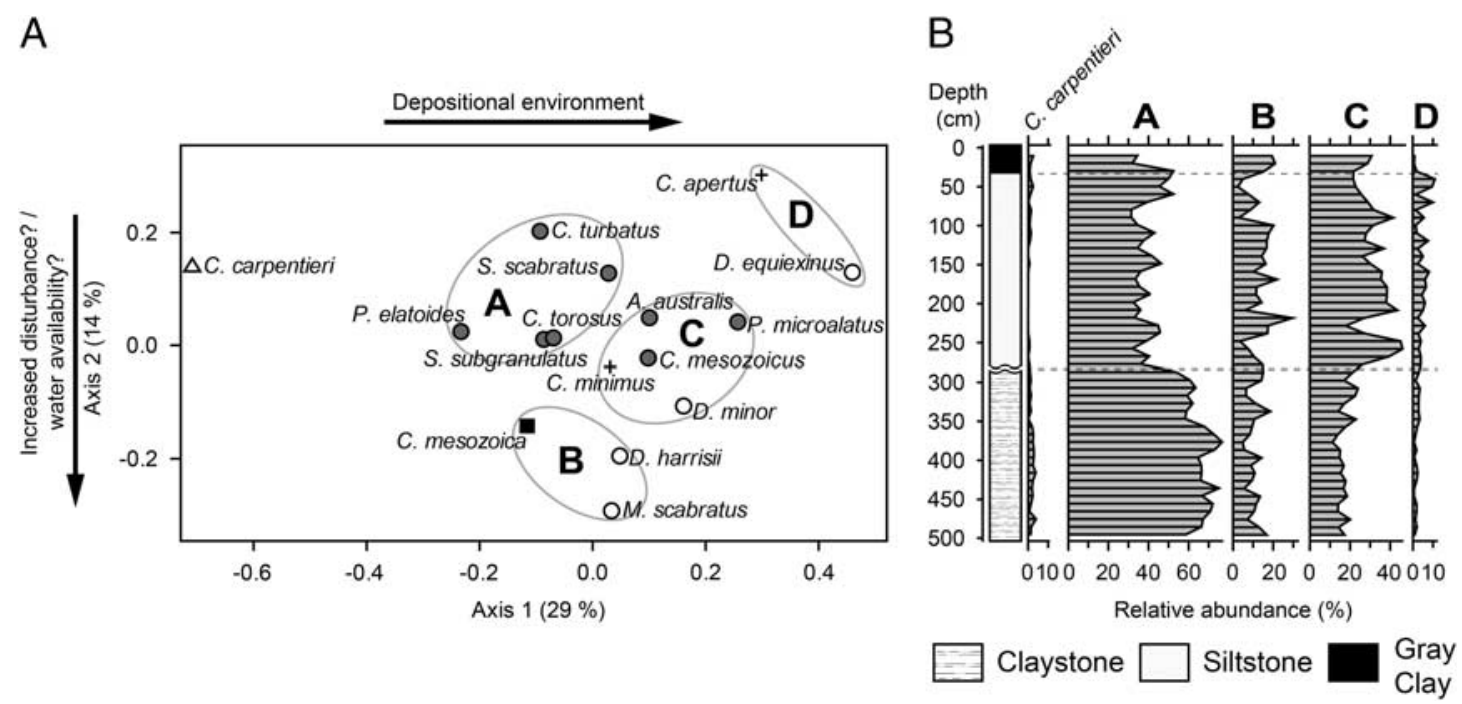

FIGURE 7. A, Correspondence analysis of taxa using logarithmically transformed sporomorph relative abundance data (excluding spiked Lycopodium). Squares represent sphenophytes; white circles represent ferns; gray circles represent conifers; crosses represent Cycadopsida/Ginkgopsida; triangles represent Bennettitales. Ellipses A-D show clustering of plots. B, Relative abundances of grouped taxa from clusters A-D from Figure 7A.

distinct abundance pattern between different lithological/depositional units that correlate with variation on axis one (29\% variation), signifying axis one corresponds to depositional setting.

The conifer dominated clusters A and C represent possible upland communities, as conifers are typical of upland and well-drained settings (e.g., Stukins et al. 2013). Megafloral studies have hypothesized that Mesozoic ferns were typical of areas of high disturbance and water supply (Harris 1961b; van Konijnenburg-van Cittert and van der Burgh 1989; Stukins et al. 2013). The co-occurrence of Sphenophyta and fern spores in cluster B is suggestive of such a community. Ascribing a specific control for axis two (14\% variation) with confidence is problematic as this could be one of a myriad of possible factors related to the principal driving mechanisms of vegetation dynamics; differential site availability, species availability and species performance (Picket and Cadenasso 2005; Stukins et al. 2013).

Palynofacies Analysis.-Two palynofacies are recognized that correspond directly with lithological variation, herein referred to as palynofacies 1 and 2. Palynofacies 1 represents the gray clay and siltstone assemblage (samples HB1-HB28) and palynofacies 2 represents the claystone assemblage (samples HB29-HB50). Relative abundances of organic debris are provided in Figure 8. Palynofacies 1 is dominated by inertinite $(\sim 43 \%)$ and unstructured vitrinite $(\sim 31 \%)$. Palynofacies 2 comprises a more heterogeneous mixture of organic debris and is co-dominated by AOM $(\sim 23 \%)$, pollen $(\sim 23 \%)$, inertinite $(\sim 21 \%)$ and unstructured vitrinite ( 17\%).

Comparison of Sporomorph and Plant Megafossil Assemblages.-A direct comparison of sporomorph and plant megafossil abundance variation through the plant bed is provided in Figure 5. A comparison of the sporomorph and plant megafossil diversity (richness) data is provided in Figure 9. Sporomorph assemblages are more diverse (67 taxa) than megafossil assemblages (49 taxa in Spicer and Hill 1979).

Bryophytes are represented by two species in sporomorph assemblages and are very low in abundance through the section (Figs. 5, 9). Bryophytes are absent from megafossil assemblages (Spicer and Hill 1979).

Lycopsids are highly diverse (16 taxa) within the sporomorph assemblage, however they are absent from megafossil counts (Fig. 9) (Spicer and Hill 1979). Abundances are low through the section within sporomorph assemblages (Fig. 5). 


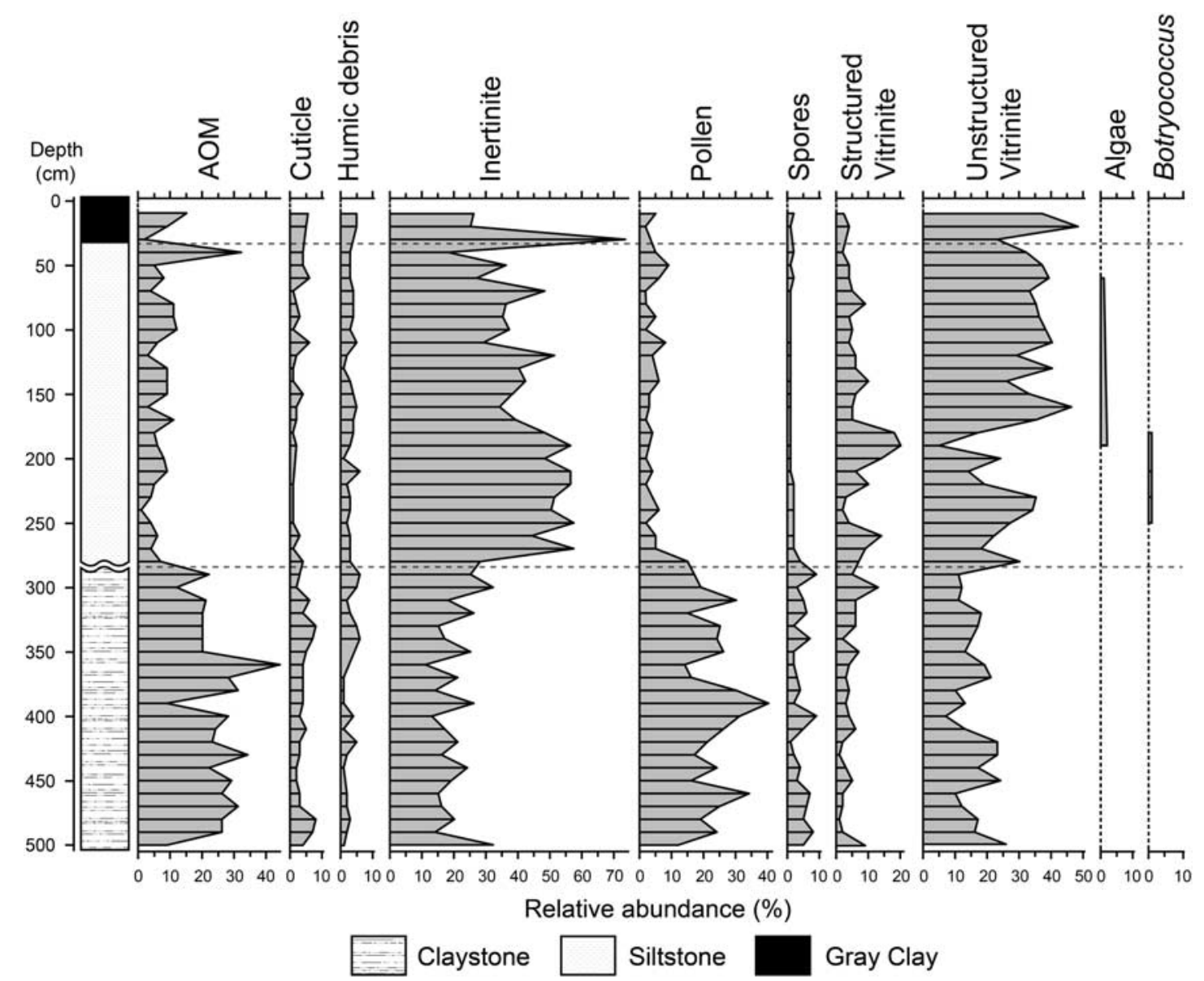

FIGURE 8. Relative abundance chart of palynofacies categories.

Sphenophytes are markedly more abundant within the megafossil assemblage (Fig. 5B) and diversity is the same (one species) in both sporomorph and megafossil assemblages (Fig. 9). Abundances are relatively constant through the section within sporomorph assemblages, however, megafossil assemblages record an increase in abundance within the siltstone compared to the claystone (Fig. 5).

Ferns are the most diverse plant group within sporomorph assemblages at Hasty Bank. Abundances (Fig. 5) and diversities (Fig. 9) are considerably higher within sporomorph assemblages (23 taxa) compared to megafossil assemblages (nine taxa). Abundances increase through the section in both sporomorph and plant megafossil assemblages (Fig. 5).

Pteridosperms are considerably more abundant (Fig. 5) and diverse (Fig. 9) within

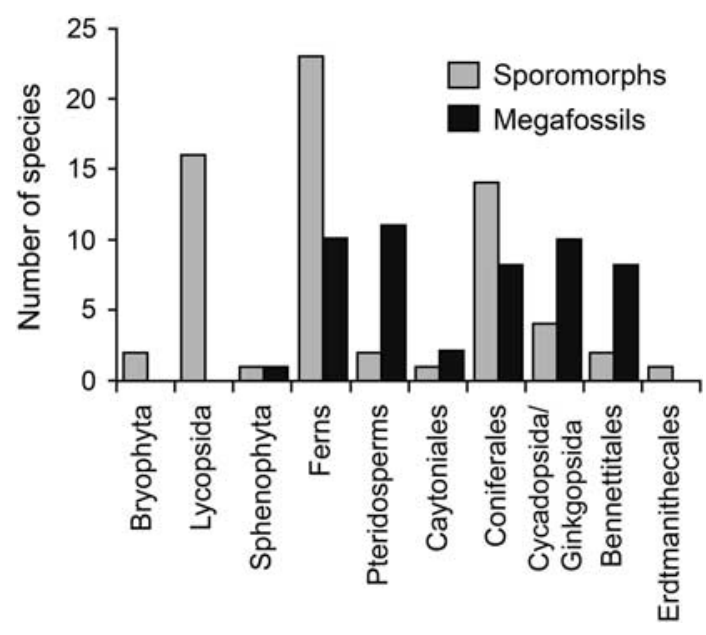

FIgURE 9. Comparative diversities (richness) of the dominant plant groups within sporomorph and plant megafossil assemblages. 
megafossil assemblages (11 taxa) compared to sporomorph assemblages (two taxa). Interestingly, sporomorph and megafossil assemblages display conflicting records for pteridosperm temporal abundance variation. Specifically, megafossil assemblages record a large decrease in pteridosperm abundances across the claystonesiltstone boundary, however in sporomorph samples, pteridosperm abundances are slightly higher within the siltstone unit.

Caytoniales are more abundant (Fig. 5) and diverse (Fig. 9) in megafossil assemblages (two taxa) compared to sporomorph assemblages (one taxa). Both sporomorph and megafossil assemblages document a slight increase in Caytoniales abundance within the siltstone unit (Fig. 5).

Coniferales are the most abundant plant group within sporomorph assemblages (Fig. 5A) and diversity is high (14 taxa) (Fig. 9). Abundance (Fig. 5B) and diversity (eight taxa) (Fig. 9) in megafossil assemblages is considerably lower. Abundances decrease through the section in both sporomorph and megafossil assemblages (Fig. 5).

Cycadopsida/Ginkgopsida are considerably more abundant (Fig. 5) and diverse (Fig. 9) within megafossil assemblages (10 taxa), compared to sporomorph assemblages (four taxa). Abundances of Cycadopsida/Ginkgopsida display little change through the section within sporomorph assemblages (Fig. 5A). Conversely, abundances of Cycadales and Ginkgoales decrease through the section within megafossil assemblages (Fig. 5B).

Bennettitales are notably more abundant (Fig. 5) and diverse (Fig. 9) in megafossil assemblages (eight taxa), compared to sporomorph assemblages (two taxa). Abundances are slightly higher in the siltstone unit within both sporomorph and plant megafossil assemblages (Fig. 5).

\section{Discussion}

Depositional Environments.-The sedimentology and palynofacies of the claystone indicates a low energy, low oxygen and high nutrient depositional environment. The occurrence of Tasmanites spp. and Crassosphaera spp. from samples HB50 to HB4 reveals a marine component through the plant bed and suggests periodic flooding by seawater, as described by Harris (1964). However, Tasmanites spp. and Crassosphaera spp. are very rare (typically less than one specimen per 1000 palynomorphs) and the presence of Botryococcus and absence of dinoflagellates in palynofacies counts demonstrates dominantly fresh water conditions (Gray 1960; Tyson 1995). The possibility that the rare marine palynomorphs could be reworked, potentially from the underlying marine Dogger Formation, cannot be discounted. Abundant AOM in claystone samples indicates relatively low oxygen and high nutrient levels within the original water during deposition (Tyson 1995; Roncaglia 2004; Traverse 2007; Pacton et al. 2011). It is difficult to state with certainty a definitive depositional setting for the claystone, however the results of this study agree with Harris' (1964) interpretations and are suggestive of a coastal plain periodically flooded by seawater, occupied by mangrovelike vegetation.

Interpretations of the depositional environment for the siltstone are consistent with previous studies that indicate this unit represents the slow moving part of a fluvial channel (Hill and van Konijnenburg-van Cittert 1973; van Konijnenburg-van Cittert and Morgans 1999). Decreased abundances of AOM signify lower nutrient levels than the claystone (Tyson 1995).

The absence of marine palynomorphs in the gray clay demonstrates marine influence is negligible to absent. Sample ordination (Fig. 6) reveals that the gray clay is compositionally more similar to the siltstone than the claystone. Sporomorph assemblages of the gray clay contain higher abundances of ferns and lower abundances of wind blown taxa, suggesting a smaller catchment area and reduced sporomorph transportation distances compared to the claystone and siltstone (Chaloner and Muir 1968). These combined factors are suggestive of a swamp or an abandoned channel environment for the gray clay.

Taphonomical models of time-averaging verses catchment area for multiple depositional environments demonstrate that the components of fossil assemblages can be used to indicate their temporal and spatial 
representations (Behrensmeyer and Kidwell 1985; Behrensmeyer et al. 2000). Fossil assemblages that contain transported plant megafossils are typical of floodplain, pond and lake deposits. Such deposits generally represent time periods of $\sim 100-10,000$ years and source areas of $\sim 100,000 \mathrm{~m}^{2}$. Sporomorphs are generally representative of larger source areas, frequently in excess of 1,000,000 $\mathrm{m}^{2}$ (Behrensmeyer et al. 2000). Estimates of source areas and time-averaging for floodplain and channel environments are highly variable (Behrensmeyer et al. 2000). Channels generally represent increased time-averaging and source area sizes compared to floodplain deposits, although there is significant overlap in source area sizes and the degree of time-averaging between channels and floodplains. Interestingly, the claystone unit (coastal plain) at Hasty Bank is interpreted to represent a longer time interval and a larger source area than the siltstone (fluvial channel) due to slower sedimentation rates and the probability that numerous rivers potentially flowed into the coastal plain environment.

Explanations for Temporal Sporomorph Variation.-Variation in sporomorph and plant megafossil assemblages through the section can be correlated strongly with depositional change. The depositional environment is a primary control on parent vegetation, thus a change in depositional setting typically results in a change in sporomorph and megafossil assemblages. The erosional surface between the claystone and siltstone separates two distinct depositional environments by a period of unknown duration; therefore a change in floral composition between the claystone and the upper part of the section (siltstone and gray clay) is not particularly surprising. Although the claystone and gray clay are more similar to each other in terms of lithology than they are to the siltstone, the reason for their differing sporomorph assemblages is attributed to their different depositional environments and associated variable catchment areas.

The higher number of sporomorphs within the claystone unit is a result of a combination of ecological and non-ecological variables. Non-ecological variables include lithological factors, sedimentation rates and the depositional environment. Although governed by the depositional environment, the lithology itself can impact on the preservation of sporomorphs and therefore result in apparent temporal floral variation. Spores and pollen can be considered as sedimentary particles during transportation and depositional processes; hence certain taxa are preferentially preserved based on factors such as particle size, particle shape and durability (Traverse 2007). Thus, changes in transportation and depositional processes between claystone, siltstone and gray clay units would have presumably resulted in the preferential preservation of particular taxa based on these physical factors. The preservation potential of sporomorphs is generally increased when sediment grain size is reduced and sedimentation rates are slower (Traverse 2007). Therefore, the high number of sporomorphs and high diversities within the claystone are probably a result of the relatively small grain size and slow sedimentation rates of this unit. Conversely, the siltstone is considered to have been deposited more rapidly than the claystone, thus the lower abundances and diversities of coniferous pollen within the siltstone are probably a result of faster sedimentation rates, as there would have been less time for such pollen "rain" to accumulate. The lower diversities within the siltstone compared to the claystone are also a consequence of the smaller catchment area supplying this deposit with sporomorphs. Specifically, the channel environment of the siltstone would have presumably had fewer tributaries feeding this deposit compared to the numerous rivers that would have potentially flowed into the coastal plain setting of the claystone.

Spicer and Hill (1979) postulated that differential rates of compaction could have affected floral compositions between lithologies. This could have had some influence on abundances; however, there is no conclusive sedimentological evidence that suggests compaction was vastly different between lithologies. The differential sedimentation rates and sediment grain sizes between depositional environments are considered to be far larger contributors to such abundance differences. For example, diversity is likely to be lower 
TABLE 1. Sporomorph dispersal methods, sporomorph production levels, and relative parent plant heights of modern equivalents of the major plant groups in the Hasty Bank plant bed.

\begin{tabular}{|c|c|c|c|c|}
\hline Plant group & $\begin{array}{l}\text { Typical sporomorph } \\
\text { dispersal method }\end{array}$ & $\begin{array}{l}\text { Typical sporomorph } \\
\text { production level }\end{array}$ & $\begin{array}{l}\text { Typical modern equivalent } \\
\text { parent plant heights }\end{array}$ & References \\
\hline Bryophyta & Mostly wind & Relatively high & Very low (Some epiphytic) & Pohjamo et al. 2006 \\
\hline Lycopsida & Mostly wind & High & Low (Some epiphytic) & $\begin{array}{l}\text { Brack-Hanes 1981; } \\
\text { Traverse } 2007\end{array}$ \\
\hline Sphenophyta & Wind & High & Relatively small & $\begin{array}{l}\text { van Konijnenburg-van } \\
\text { Cittert and Morgans } \\
1999\end{array}$ \\
\hline Ferns & Mostly wind & Very High & $\begin{array}{l}\text { Variable, mostly low } \\
\text { (Some epiphytic) }\end{array}$ & $\begin{array}{l}\text { Durand and Goldstein } \\
2001\end{array}$ \\
\hline Pteridosperms & $\begin{array}{l}\text { Mostly wind, some } \\
\text { potentially insect }\end{array}$ & - & - & Labandeira et al. 2007 \\
\hline Caytoniales & Wind and ?insect & - & - & $\begin{array}{l}\text { Harris 1933, 1945; } \\
\text { Schwendemann et al. } \\
\text { 2007; Ren et al. 2009; } \\
\text { Labandeira } 2010\end{array}$ \\
\hline Coniferales & Wind & Very high & Variable, mostly very tall & $\begin{array}{l}\text { Critchfield 1985; van } \\
\text { Konijnenburg-van } \\
\text { Cittert and Morgans } \\
1999\end{array}$ \\
\hline Cycadales & Wind and insect & $\begin{array}{l}\text { Variable (Relatively high } \\
\text { in wind pollinated } \\
\text { taxa, low in wind and } \\
\text { insect pollinated taxa) }\end{array}$ & $\begin{array}{l}\text { Variable, low to } \\
\text { moderately tall }\end{array}$ & Norstog 1987 \\
\hline Ginkgoales & Wind and ?insect & High & Very tall & $\begin{array}{l}\text { Del Tredici 1989; van } \\
\text { Konijnenburg-van } \\
\text { Cittert 2010; Crane } \\
\text { 2013; Bhowmik and } \\
\text { Parveen } 2014\end{array}$ \\
\hline Bennettitales & Wind and ?insect & - & - & Crepet et al. 1991 \\
\hline
\end{tabular}

within the fluvial siltstone (compared to the same unit of claystone), because it was deposited more rapidly.

Ecological Causes for Variation between Sporomorph and Plant Megafossil Assemblages.Table 1 shows the generalized sporomorph dispersal methods of the dominant plant groups through the Hasty Bank plant bed. The majority of plant groups in Table 1 rely on wind to disperse sporomorphs. The life habits and reproductive methods of wind dispersed taxa result in abundance and diversity discrepancies between the sporomorph and megafossil assemblages. Pollen and spore production in wind dispersed species is typically very high as the efficiency of wind pollination increases as the concentration of airborne pollen increases (Regal 1982; Whitehead 1983; Allison 1990; Friedman and Barrett 2009). The sporomorph and megafossil records at Hasty Bank reflect this bias; conifers and ferns that produce vast numbers of pollen and spores are considerably more abundant
(Fig. 5) and diverse (Fig. 9) within sporomorph assemblages.

The nature of wind pollination means that sporomorph assemblages capture spores and pollen from a significantly larger geographic area compared to plant megafossil assemblages, which are more representative of the local paleoflora (e.g., Prentice 1985). Many of the coniferous species within the sporomorph assemblage are therefore potentially not representative of the flora close to the site of deposition and are possibly more indicative of upland communities.

The physical size of parent plants also impacts on the composition of sporomorph assemblages. Pollen released at elevated heights increases dispersal distances as: (1) wind speeds are greater, (2) pollen remains within the airstream longer, and (3) there is usually less intervening vegetation to intercept pollen (Levin and Kerster 1974; Okubo and Levin 1989; Friedman and Barrett 2009). Many coniferous sporomorph taxa from the Hasty Bank plant 
bed originate from large trees; this is a principal factor contributing to their high abundances within sporomorph assemblages.

Harris (1964) described the pollen organ Pteroma thomasi from Hasty Bank and associated this with the pteridosperm $P$. papillosa based on their similar cuticles and co-occurrence. The pollen of $P$. thomasi is most similar to the wind dispersed pollen of Alisporites thomasii (Harris 1964; Ziaja 2006). Spicer and Hill (1979) demonstrated that the parent plant, $P$. papillosa is markedly more abundant within the claystone, however the dispersed pollen, A. thomasii does not record this abundance change and is low in abundance throughout the section. Temporal changes in local vegetation are generally less well recorded among wind dispersed taxa in the sporomorph record as such taxa are captured from larger geographic areas than corresponding megafossils.

Animal-plant interactions could also be a cause of inconsistencies between sporomorph and plant megafossil assemblages. Potential insect assisted pollination in Caytoniales (Harris 1945; Labandeira 2010) could be a cause of the underrepresentation of such pollen in sporomorph assemblages (Figs. 5 and 9) as pollen production in insect pollinated plants is typically very low compared to wind dispersed taxa (e.g., Norstog 1987).

Cycads and Bennettitales display markedly lower abundances (Fig. 5) and diversities (Fig. 9) within the sporomorph record. The reproductive methods of these plants differ considerably from the exclusively wind dispersed conifers and ferns. Some modern cycads rely on a combination of wind and insect pollination (Niklas and Norstog 1984; Clark and Clark 1987; Tang 1987; Norstog and Fawcett 1989; Ornduff 1990; Pellmyr et al. 1991; Wilson 2002; Kono and Tobe 2007; Terry et al. 2007), and both fossil cycads and Bennettitales display early evidence of possible insect pollination (Crepet et al. 1991; Klavins et al. 2005; Labandeira et al. 2007). Pollen production varies greatly among modern cycads, depending on whether wind or insect pollination is dominant (Norstog 1987). Kono and Tobe (2007) demonstrated that the pollen of the modern cycad, Cycas revoluta occurs only in abundance within very close proximity $(\sim 2 \mathrm{~m})$ to the cones from which it is released. If Jurassic cycads share such a characteristic, cycad pollen would almost certainly be underrepresented in the sporomorph assemblage. Nilssonia kendalliae is the most common species within megafossil counts, constituting $\sim 29 \%$ of the total assemblage (Spicer and Hill 1979). Harris (1964) presumed $N$. kendalliae to be of cycad or pteridosperm affinity. In situ pollen studies have associated the pollen Androstrobus with N. kendalliae (van Konijnenburg-van Cittert 1968) and more generally Nilssoniaceae (Hill 1990). In situ Androstrobus pollen is considered to be equivalent to dispersed Chasmatosporites pollen (Balme 1995). As a genus Chasmatosporites constitutes only $\sim 2.9 \%$ of the total sporomorph assemblage. This abundance discrepancy is interpreted to be due to low pollen production and small dispersal ranges of cycads compared to many of the wholly wind pollinated plants. Hence, the specialized reproductive nature of cycads, Bennettitales and potentially Caytoniales (Delevoryas 1963; Harris 1974; Labandeira 2010; Mander et al. 2010) is probably the principal factor contributing to their underrepresentation in sporomorph assemblages.

The underrepresentation of cycads, Bennettitales and ginkgos in the sporomorph diversity record is potentially compounded by recognition biases. The leaves of these groups typically possess distinctive morphological features that enable easy differentiation to generic and species level (Lidgard and Crane 1990), thus the diversity of such taxa in the megafossil assemblage is high. However, the pollen of these groups is often simple and monosulcate, with little morphological and sculptural variation visible under light microscopy (Frederiksen 1980). Sporomorph species therefore potentially represent numerous parent plant species, thus diversity in the dispersed sporomorph record is underrepresented.

The high diversities of lycopsids, ferns and bryophytes in sporomorph assemblages compared to megafossil assemblages (Fig. 9) could be related to epiphytic communities. Epiphytes are generally poorly represented in the megafloral record as the burial and subsequent fossilization of such species is unlikely 
compared to most other plants (Schneider and Kenrick 2001; Frahm and Newton 2005; Tstutsumi and Kato 2006; Schuettpelz and Pryer 2007, 2009; Dubuisson et al. 2009; Pšenička and Opluštil 2013). In contrast, sporomorphs released from epiphytes do not experience this bias, thus diversities of epiphytic groups are comparatively unaffected in the sporomorph record.

The absence of lycopsids and low diversity of ferns in megafossil assemblages could also be linked to the relatively low preservation potential of many non-arborescent species. Scheihing (1980) demonstrated that non-arborescent taxa are frequently underrepresented in the megafloral record as a result of: (1) the increased biomass of arborescent species, (2) difficulty in recognition of nonarborescent plant parts, and (3) shielding of the non-arborescent understory by the arborescent canopy during high energy transport and depositional processes.

Variation in Plant and Sporomorph Durability Causing Megafossil-Sporomorph Inconsistencies.Many of the inconsistencies between the plant megafossil and sporomorph assemblages are interpreted to be a result of differences in durability between parent plants and associated sporomorphs.

Equisetum columnare is the second most abundant plant species in megafossil assemblages, constituting $\sim 19 \%$ of the megaflora (Spicer and Hill 1979). However, its corresponding microspore, C. mesozoica represents only $\sim 2.5 \%$ of the sporomorph assemblage. This discrepancy is probably due to the highly durable nature of Equisetum, which means that this genus is overrepresented compared to other megafloral taxa. Conversely, C. mesozoica has a low preservation potential due to its thin wall and low sporopollenin content (Traverse 2007; Grauvogel-Stamm and Lugardon 2009), thus this species is underrepresented in the sporomorph assemblage. These combined factors give rise to a notable differential preservation potential between the parent plant and sporomorph.

The high diversity of lycopsids (16 taxa) in sporomorph assemblages and their absence from megafossil assemblages suggests an extremely low preservation potential for lycopsid remains within this deposit. The same pattern is also present within Triassic-Jurassic plant beds from East Greenland (Mander et al. 2010, 2013) and Lower Jurassic deposits of Odrowąż, central Poland (Ziaja 2006). Lycopsids are notable both for their diversity in the megaspore record of the Middle Jurassic deposits of Yorkshire (reviewed in Slater et al. 2015) and for their lack of megafossils within these deposits. Harris (1961b) summarizes studies on the lycopsid megafossil Selaginellites falcatus. With the exception of this species there are no other convincing reports of lycopsid megafossils from the Middle Jurassic of Yorkshire (Lindley and Hutton 1833; Hill et al. 1985; Schweitzer et al. 1997). The absence of lycopsid megafossils may also be exacerbated by the lack of recognition of delicate lycopsid remains (Skog and Hill 1992).

Are Sporomorphs or Plant Megafossils More Informative regarding Paleofloristic Reconstructions?-Comparison of palynological and plant megafossil records demonstrates that respective data sets reflect different aspects of the paleoflora as they preferentially preserve certain taxa based on a multitude of ecological and non-ecological variables. Such variables include spore/pollen and plant durability, absolute abundances of plant species in life, proximity of parent plants to depositional location, spore/pollen dispersal methods, spore/pollen dispersal distances, absolute numbers of spores/pollen released from parent plants, transportation distances, transportation processes, climatic variations, and the depositional environment. This study illustrates that sporomorphs preserve some aspects of the paleoflora more completely (mostly wind dispersed taxa) than megafossil assemblages. However, megafossil assemblages equally preserve other aspects of the paleoflora (mostly reproductively specialized taxa) more completely than sporomorph assemblages.

Direct quantitative comparative studies of dispersed sporomorph and plant megafossil assemblages from pre-angiosperm Mesozoic floras are relatively uncommon in the literature due to the rarity of such fossil sites (e.g., Pedersen and Lund 1980; Ziaja 2006; Mander et al. 2010). Most previous studies that incorporate dispersed sporomorphs and plant 
megafossils are confined to Paleozoic (e.g., Looy and Hotton 2014), Cretaceous (e.g., Lidgard and Crane 1990; Bercovici et al. 2008, 2009) and Cenozoic (e.g., Tinner et al. 1996; Wing and Harrington 2001) floras. These floras are fundamentally different to pre-angiosperm Mesozoic communities, thus comparison of such floras with those at Hasty Bank is highly problematic. Rare examples where combined sporomorph and megafossil data have been used in vegetation reconstructions from pre-angiosperm Mesozoic floras demonstrate consistency with findings from Hasty Bank. Specifically, conifers and ferns are typically well represented in sporomorph assemblages (Jana and Hilton 2007), cycads, Bennettitales and pteridosperms are generally well represented in megafossil assemblages (Pedersen and Lund 1980; Götz et al. 2011), and bryophytes and lycopsids are often confined to sporomorph assemblages (Ziaja 2006; Mander et al. 2010, 2013). Such large discrepancies between parent plant and dispersed sporomorph assemblages questions the reliability of local vegetation reconstructions based on megafossil or sporomorph evidence in isolation and suggests that where possible a combined approach is considerably more informative.

\section{Conclusions}

Variation in sporomorph assemblages through the Hasty Bank plant bed is the result of a change in depositional setting between the three lithological units. Changes in the depositional environments consequently influence the vegetation, catchment areas, and preservation potential of sporomorphs and plant megafossils; hence the fossil assemblages vary notably between lithologies. Discrepancies between sporomorph and plant megafossil assemblages are primarily a result of the different life habits and reproductive strategies employed by parent plants. Such differences often cause large variation in sporomorph production and dispersal distances. Differential preservation potentials between parent plants and associated spores/pollen also has a substantial impact on generating inconsistencies between sporomorph and plant megafossil data sets. This is particularly apparent regarding the absence of lycopsids and the elevated abundances of E. columnare in plant megafossil assemblages (Spicer and Hill 1979). Based on the results at Hasty Bank and similar studies (e.g., Ziaja 2006; Mander et al. 2010; 2013), explaining discrepancies between sporomorph and plant megafossil assemblages requires considerable analysis and there is no "best" method of reconstructing paleofloras. Assemblage compositions are the product of a complex array of biological, geographical, and depositional factors that act inconsistently between and within sporomorph and megafossil assemblages, resulting in notable disparities between respective data sets. Refining parent plant affinities with spore and pollen in situ studies will aid in future reconstructions of paleofloras using dispersed sporomorphs.

\section{Acknowledgments}

We thank J. L. Clark and C. R. Hill for their help with collection of samples. C. R. Hill also provided useful comments throughout this research. B. J. Slater and T. M. Young also helped with fieldwork. S. Ellin provided laboratory support. D. Cameron provided advice on statistical methods. This research forms part of a Ph.D. studentship to SMS at the University of Sheffield funded by a Natural Environment Research Council CASE Award with Royal Dutch Shell, jointly supervised by C. H. Wellman and I. Prince. Finally, we thank M. Kowalewski, A. Bercovici and three anonymous reviewers for their comments, which significantly improved this paper.

\section{Literature Cited}

Alexander, J. 1989. Delta or coastal plain? With an example of the controversy from the Middle Jurassic of Yorkshire. Geological Society, London, Special Publications 41:11-19.

— 1992. A discussion of alluvial sandstone body characteristics related to variations in marine influence, Middle Jurassic of the Cleveland Basin, UK, and the implications for analogous Brent Group strata in the North Sea Basin. Geological Society, London, Special Publications 61:149-167.

Allison, T. D. 1990. Pollen production and plant density affect pollination and seed production in Taxus canadensis. Ecology 71:516-522.

Balme, B. E. 1995. Fossil in situ spores and pollen grains: an annotated catalogue. Review of Palaeobotany and Palynology $87: 81-323$ 
Batten, D. J., and R. J. Dutta. 1997. Ultrastructure of exine of gymnospermous pollen grains from Jurassic and basal Cretaceous deposits in northwest Europe and implications for botanical relationships. Review of Palaeobotany and Palynology 99:25-54.

Batten, D. J., and D. T. Stead. 2005. Palynofacies analysis and its stratigraphic application. Pp. 203-226 in E. A. M. Koutsoukos, ed. Applied stratigraphy. Springer, Netherlands.

Behrensmeyer, A. K., and S. M. Kidwell. 1985. Taphonomy's contributions to paleobiology. Paleobiology 11:105-119.

Behrensmeyer, A. K., S. M. Kidwell, and R. A. Gastaldo. 2000. Taphonomy and paleobiology. Paleobiology 26:103-147.

Bercovici, A., D. Nichols, and D. Pearson. 2008. Detailed palaeontologic and taphonomic techniques to reconstruct an earliest Paleocene fossil flora: an example from southwestern North Dakota, USA. Review of Palaeobotany and Palynology 151:136-146.

Bercovici, A., D. Pearson, D. Nichols, and J. Wood. 2009. Biostratigraphy of selected K/T boundary section in southwestern North Dakota, USA: toward a refinement of palynological identification criteria. Cretaceous Research 30:632-658.

Bhowmik, N., and S. Parveen. 2014. Fossilized pollination droplet in a new seed genus from the Middle Triassic of Nidpur, India. Acta Palaeontologica Polonica 59:491-503.

Black, M. 1929. Drifted plant-beds of the Upper Estuarine Series of Yorkshire. Quarterly Journal of the Geological Society 85:389-439.

Bonis, N. R., and W. M. Kürschner. 2012. Vegetation history, diversity patterns, and climate change across the Triassic/ Jurassic boundary. Paleobiology 38:240-264.

Boulter, M., and A. Riddick. 1986. Classification and analysis of palyno-debris from the Palaeocene sediments of the Forties Field. Sedimentology 33:871-886.

Boulter, M., and T. Windle. 1993. A reconstruction of some Middle Jurassic vegetation in northern Europe. Special Papers in Palaeontology 49:125-154.

Bowman, V. C., J. E. Francis, R. A. Askin, J. B. Riding, and G. T. Swindles. 2014. Latest Cretaceous-earliest Paleogene vegetation and climate change at the high southern latitudes: palynological evidence from Seymour Island, Antarctic Peninsula. Palaeogeography, Palaeoclimatology, Palaeoecology 408:26-47.

Brack-Hanes, S. D. 1981. On a lycopsid cone with winged spores. Botanical Gazette 142:294-304.

Brugman, W. A., P. F. Van Bergen, and J. H. F. Kerp. 1994. A quantitative approach to Triassic palynology: the Lettenkeuper of the Germanic Basin as an example. Pp. 409-430 in A. Traverse, ed. Sedimentation of organic particles. Cambridge University Press, Cambridge.

Butler, N., M. A. Charnock, K. O. Hager, and C. A. Watkins. 2005. The Ravenscar Group: a coeval analogue for the Middle Jurassic reservoirs of the North Sea and offshore Mid-Norway. Pp. 43-53 in A. J. Powell and J. B. Riding, eds. Recent developments in applied biostratigraphy. Geological Society of London, Micropaleontological Society Special Publications, London.

Carvalho, M. D. A., J. G. M. Filho, and T. R. Menezes. 2006. Paleoenvironmental reconstruction based on palynofacies analysis of the Aptian-Albian succession of the Sergipe Basin, northeastern Brazil. Marine Micropaleontology 59:56-81.

Chaloner, W. G. 1968. The palaeoecology of fossil spores. Pp. 125-138 in E. T. Drake, ed. Evolution and environment. Yale University Press, New Haven, Connecticut, USA.

Chaloner, W. G., and M. Muir. 1968. Spores and floras. Pp. 127-146 in D. Murchison, and T. S. Westoll, eds. Coal and coal-bearing strata. Oliver and Boyd, Edinburgh and London.

Chatfield, C., and A. J. Collins. 1980. Introduction to multivariate analysis. Chapman and Hall/CRC, USA

Clark, D. A., and D. B. Clark. 1987. Temporal and environmental patterns of reproduction in Zamia skinneri, a tropical rain forest cycad. Journal of Ecology 75:135-149.
Colwell, R. K., and J. A. Coddington. 1994. Estimating terrestrial biodiversity through extrapolation. Philosophical Transactions of the Royal Society of London B 345:101-118.

Couper, R. A. 1958. British Mesozoic microspores and pollen grains. Palaeontographica Abteilung B 103:75-179.

Cox, T. F., and M. A. A. Cox. 2001. Multidimensional scaling, second edition. Chapman and Hall/CRC, USA.

Cox, B. M., and M. G. Sumbler. 2002. British Middle Jurassic stratigraphy. Geological Conservation Review Series, Peterborough

Crane, P. R. 2013. Ginkgo: the tree that time forgot. Yale University Press, New Haven, Connecticut, USA.

Crane, P. R., and P. S. Herendeen. 2009. Bennettitales from the Grisethorphe Bed (Middle Jurassic) at Cayton Bay, Yorkshire, UK. American Journal of Botany 96:284-295.

Crepet, W., E. M. Friis, and K. C. Nixon. 1991. Fossil evidence for the evolution of biotic pollination. Philosophical Transactions of the Royal Society of London B 333:187-195.

Critchfield, W. B. 1985. The late Quaternary history of lodgepole and jack pines. Canadian Journal of Forest Research 15:749-772.

Delevoryas, T. 1963. Investigations of North American cycadeoids: cones of Cycadeoidea. American Journal of Botany 50:45-52.

Del Tredici, P. 1989. Ginkgos and multituberculates: evolutionary interactions in the Tertiary. Biosystems 22:327-339.

Dettmann, M. E. 1963. Upper Mesozoic microfloras from southeastern Australia. Proceedings of the Royal Society of Victoria 77:1-148.

Dubuisson, J. Y., H. Schneider, and S. Hennequin. 2009. Epiphytism in ferns: diversity and history. Comptes Rendus Biologies 332:120-128.

Durand, L. Z., and G. Goldstein. 2001. Growth, leaf characteristics, and spore production in native and invasive tree ferns in Hawaii. American Fern Journal 91:25-35.

Filatoff, J. 1975. Jurassic palynology of the Perth Basin, Western Australia. Palaeontographica Abteilung B 154:1-113.

Fisher, M. J., and N. J. Hancock. 1985. The Scalby Formation (Middle Jurassic, Ravenscar Group) of Yorkshire: reassessment of age and depositional environment. Proceedings of the Yorkshire Geological Society 45:293-298.

Frahm, J. P., and A. E. Newton. 2005. A new contribution to the moss flora of Dominican amber. The Bryologist 108:526-536.

Frederiksen, N. O. 1980. Significance of monosulcate pollen abundance in Mesozoic sediments. Lethaia 13:1-20.

Friedman, J., and S. C. H. Barrett. 2009. Wind of change: new insights on the ecology and evolution of pollination and mating in wind-pollinated plants. Annals of Botany 103:1515-1527.

Friis, E. M., and K. R. Pedersen. 1996. Eucommiitheca hirsuta, a new pollen organ with Eucommiidites pollen from the Early Cretaceous of Portugal. Grana 35:104-112.

Gedl, P., and J. Ziaja. 2012. Palynofacies from Bathonian (Middle Jurassic) ore-bearing clays at Gnaszyn, Kraków-Silesia Homocline, Poland, with special emphasis on sporomorph eco-groups. Acta Geologica Polonica 3:325-349.

Götz, A. E., K. Ruckwied, and M. Barbacka. 2011. Palaeoenvironment of the Late Triassic (Rhaetian) and Early Jurassic (Hettangian) Mecsek Coal Formation (south Hungary): implications from macro- and microfloral assemblages. Palaeobiodiversity and Palaeoenvironments 91:75-88.

Gowland, S., and J. B. Riding. 1991. Stratigraphy, sedimentology and palaeontology of the Scarborough Formation (Middle Jurassic) at Hundale Point, North Yorkshire. Proceedings of the Yorkshire Geological Society 48:375-392.

Grauvogel-Stamm, L., and B. Lugardon. 2009. Phylogeny and evolution of the horsetails: evidence from spore wall ultrastructure. Review of Palaeobotany and Palynology 156: 116-129.

Gray, J. 1960. Fossil chlorophycean algae from the Miocene of Oregon. Journal of Paleontology 34:453-463. 
Greenacre, M. 2007. Correspondence analysis in practice, second edition. Chapman and Hall/CRC, Boca Raton, USA.

Guignard, G., Y. Wang, Q. Ni, N. Tian, and Z. Jiang. 2009. A dipteridaceous fern with in situ spores from the Lower Jurassic in Hubei, China. Review of Palaeobotany and Palynology 156:104-115.

Hammer, Ø., and D. T. Harper. 2006. Paleontological data analysis. Blackwell, Oxford.

Hammer, Ø., D. T. Harper, and P. D. Ryan. 2001. PAST: paleontological statistics software package for education and data analysis. Palaeontologia Electronica 4:1-9.

Hancock, N. J., and M. J. Fisher. 1981. Middle Jurassic North Sea deltas with particular reference to Yorkshire. Pp. 186-195 in L. V. Illing, and G. D. Hobson, eds. Petroleum geology of the continental shelf of north-west Europe. Institute of Petroleum, London.

Harrington, G. J. 2008. Comparisons between Palaeocene-Eocene paratropical swamp and marginal marine pollen floras from Alabama and Mississippi, USA. Palaeontology 51:611-622.

Harris, T. M. 1933. A new member of the Caytoniales. The New Phytologist 32:97-114.

—. 1941. Caytonanthus, the microsporophyll of Caytonia. Annals of Botany 5:47-58.

- 1944. Notes on the Jurassic flora of Yorkshire. Journal of Natural History Series 11:13-15.

- 1945. On a coprolite of Caytonia pollen. Annals of Magazine of Natural History Series 11, 12:357-378.

- 1952. The zonation of the Yorkshire Jurassic flora. Palaeobotanist 1:207-211.

_ 1953. The geology of the Yorkshire Jurassic flora. Proceedings of the Yorkshire Geological Society 29:63-71.

—. 1961a. The fossil cycads. Palaeontology 4:313-323.

1961b. The Yorkshire Jurassic flora I. ThallophytaPteridophyta. British Museum (Natural History), London.

— 1964 . The Yorkshire Jurassic flora II. Caytoniales, Cycadales and pteridosperms. British Museum (Natural History), London.

—. 1969. The Yorkshire Jurassic flora III. Bennettitales. British

Museum (Natural History), London.

- 1974. Williamsoniella lignieri: its pollen and the compression of spherical pollen grains. Palaeontology 17:125-148.

- 1978. A reconstruction of Equisetum columnare and notes on its elater bearing spores. Palaeobotanist 25:120-125.

—. 1979. The Yorkshire Jurassic flora V. Coniferales. British Museum (Natural History), London.

_ 1983. The stem of Pachypteris papillosa. Botanical Journal of the Linnean Society 86:149-159.

Harris, T. M., W. Millington, and J. Miller. 1974. The Yorkshire Jurassic flora IV. Ginkgoales and Czekanowskiales. British Museum (Natural History), London.

Hemingway, J. E.. 1974. Jurassic. Pp. 161-233 in D. H. Rayner, and J. E. Hemingway, eds. The geology and mineral resources of Yorkshire. Yorkshire Geological Society, Leeds.

Hemingway, J. E., and R. W. O'B. Knox. 1973. Lithostratigraphical nomenclature of the Middle Jurassic strata of the Yorkshire Basin of north-east England. Proceedings of the Yorkshire Geological Society 39:527-535.

Hill, C. R. 1974. Further plant fossils from the Hasty Bank locality. Naturalist 929:55-56.

_. 1990. Ultrastructure of in situ fossil cycad pollen from the English Jurassic, with a description of the male cone Androstrobus balmei sp. nov. Review of Palaeobotany and Palynology 65: 165-173.

Hill, C. R., and J. H. A. van Konijnenburg-van Cittert. 1973. Species of plant fossils collected from the Middle Jurassic plant bed at Hasty Bank, Yorkshire. Naturalist 925:59-63.

Hill, C. R., D. T. Moore, J. T. Greensmith, and R. Williams. 1985. Palaeobotany and petrology of a Middle Jurassic ironstone bed at Wrack Hills, North Yorkshire. Proceedings of the Yorkshire Geological Society 45:277-292.
Hubbard, R. N. L. B., and M. C. Boulter. 1997. Mid Mesozoic floras and climates. Palaeontology 40:43-70.

Jana, B. N., and J. Hilton. 2007. Resolving the age of the Mesozoic Kuar Bet Beds (Kachchh, Gujarat, India): a reinvestigation of palaeobotanical and palynological assemblages. Journal of Asian Earth Sciences 30:457-463.

Jardine, P. E., G. J. Harrington, and T. A. Stidham. 2012. Regionalscale spatial heterogeneity in the late Paleocene paratropical forests of the U.S. Gulf Coast. Paleobiology 38:15-39.

Kantorowicz, J. D. 1985. The petrology and diagenesis of Middle Jurassic clastic sediments, Ravenscar Group, Yorkshire. Sedimentology 32:833-853.

Klavins, S. D., D. W. Kellogg, M. Krings, E. L. Taylor, and T. N. Taylor. 2005. Coprolites in a Middle Triassic cycad pollen cone: evidence for insect pollination in early cycads? Evolutionary Ecology Research 7:479-488.

Knox, R. W. O'B. 1973. The Eller Beck Formation (Bajocian) of the Ravenscar Group of NE Yorkshire. Geological Magazine 110:511-534.

Kono, M., and H. Tobe. 2007. Is Cycas revoluta (Cycadaceae) wind- or insect-pollinated? American Journal of Botany 94:847-855.

Kovach, W. L. 1989. Comparisons of multivariate analytical techniques for use in pre-Quaternary plant paleoecology. Review of Palaeobotany and Palynology 60:255-282.

—. 1993. Multivariate techniques for biostratigraphical correlation. Journal of the Geological Society 150:697-705.

Labandeira, C. C. 2010. The pollination of mid Mesozoic seed plants and the early history of long-proboscid insects. Annals of the Missouri Botanical Garden 97:469-513.

Labandeira, C. C., J. Kvaček, and M. B. Mostovski. 2007. Pollination drops, pollen, and insect pollination of Mesozoic gymnosperms. Taxon 56:663-695.

Leeder, M. R., and M. Nami. 1979. Sedimentary models for the non-marine Scalby Formation (Middle Jurassic) and evidence for late Bajocian/Bathonian uplift of the Yorkshire Basin. Proceedings of the Yorkshire Geological Society 42:461-482.

Legendre, P., and L. Legendre. 2012. Numerical ecology, third edition. Elsevier, Amsterdam.

Levin, D. A., and H. Kerster. 1974. Gene flow in seed plants. Evolutionary Biology 7:139-220.

Lidgard, S., and P. R. Crane. 1990. Angiosperm diversification and Cretaceous floristic trends: a comparison of palynofloras and leaf macrofloras. Paleobiology 16:77-93.

Lindley, J., and W. Hutton. 1833. The fossil flora of Great Britain: or, figures and descriptions of the vegetable remains found in a fossil state in this country. James Ridgway, London.

Livera, S. E., and M. R. Leeder. 1981. The Middle Jurassic Ravenscar Group ('Deltaic Series') of Yorkshire: recent sedimentological studies as demonstrated during a field meeting 2-3 May 1980. Proceedings of the Geologists' Association 92: 241-250.

Looy, C. V., and C. L. Hotton. 2014. Spatiotemporal relationships among Late Pennsylvanian pant assemblages: palynological evidence from the Markley Formation, West Texas, U.S.A. Review of Palaeobotany and Palynology 211:10-27.

Mander, L. 2011. Taxonomic resolution of the Triassic-Jurassic sporomorph record in East Greenland. Journal of Micropalaeontology 30:107-118.

Mander, L., W. M. Kürschner, and J. C. McElwain. 2010. An explanation for conflicting records of Triassic-Jurassic plant diversity. Proceedings of the National Academy of Sciences of the United States of America 107:15351-15356.

- 2013. Palynostratigraphy and vegetation history of the Triassic-Jurassic transition in East Greenland. Journal of the Geological Society 170:37-46. 
Milsom, J., and P. F. Rawson. 1989. The peak trough - a major control on the geology of the North Yorkshire coast. Geological Magazine 126:699-705.

Minchin, P. 1987. An evaluation of the relative robustness of techniques for ecological ordination. Vegetatio 69:89-107.

Mjøs, R., and E. Prestholm. 1993. The geometry and organization of fluviodeltaic channel sandstones in the Jurassic Saltwick Formation, Yorkshire, England. Sedimentology 40:919-935.

Morgans, H. S. 1999. Lower and Middle Jurassic woods of the Cleveland Basin (North Yorkshire), England. Palaeontology 42:303-328.

Nami, M., and M. R. Leeder. 1978. Changing channel morphology and magnitude in the Scalby Formation (M. Jurassic) of Yorkshire, England. Pp. 431-440 in A. D. Miall, ed. Fluvial sedimentology. Canadian society of petroleum geologists memoir 5 . Calgary, Canada.

Niklas, K. J., and K. Norstog. 1984. Aerodynamics and pollen grain depositional patterns on cycad megastrobili: implications on the reproduction of three cycad genera (Cycas, Dioon, and Zamia). Botanical Gazette 145:92-104.

Norstog, K. 1987. Cycads and the origin of insect pollination. American Scientist 75:270-279.

Norstog, K. J., and P. K. S. Fawcett. 1989. Insect-cycad symbiosis and its relation to the pollination of Zamia furfuracea (Zamiaceae) by Rhopalotria mollis (Curculionidae). American Journal of Botany 76:1380-1394.

Oboh-Ikuenobe, F. E., and O. Yepes. 1997. Palynofacies analysis of sediments from the Côte d'Ivoire-Ghana transform margin: preliminary correlation with some regional events in the equatorial Atlantic. Palaeogeography, Palaeoclimatology, Palaeoecology 129:291-314.

Oboh-Ikuenobe, F. E., C. G. Obi, and C. A. Jaramillo. 2005. Lithofacies, palynofacies, and sequence stratigraphy of Palaeogene strata in southeastern Nigeria. Journal of African Earth Sciences 41:79-101.

Oksanen, J., F. G. Blanchet, R. Kindt, P. Legendre, P. R. Minchin, R. B. O'Hara, G. L. Simpson, P. Solymos, M. H. H. Stevens, and H. Wagner. 2015. Vegan: Community Ecology Package. R package, version 2.2-1. http://www.cran.r-project.org/web/packages/vegan/index.html.

Okubo, A., and S. A. Levin. 1989. A theoretical framework for data analysis of wind dispersal of seeds and pollen. Ecology 70:329-338.

Ornduff, R. 1990. Geographic variation in reproductive behavior and size structure of the Australian cycad Macrozamia communis (Zamiaceae). American Journal of Botany 77:92-99.

Osborn, J. M., and T. N. Taylor. 1993. Pollen morphology and ultrastructure of the Corystospermales: permineralized in situ grains from the Triassic of Antarctica. Review of Palaeobotany and Palynology 79:205-219.

Pacton, M., G. E. Gorin, and C. Vasconcelos. 2011. Amorphous organic matter - experimental data on formation and the role of microbes. Review of Palaeobotany and Palynology 166:253-267.

Palliani, R. B., and J. B. Riding. 2000. A palynological investigation of the Lower and lowermost Middle Jurassic strata (Sinemurian to Aalenian) from North Yorkshire, UK. Proceedings of the Yorkshire Geological Society 53:1-16.

Parry, C. C., P. K. J. Whitley, and R. D. H. Simpson. 1981. Integration of palynological and sedimentological methods in facies analysis of the Brent Formation. Pp. 205-215 in L. V. Illings, and G. D. Hobson, eds. Petroleum geology of the continental shelf of north-west Europe. Institute of Petroleum, London.

Pedersen, K. R., and J. J. Lund. 1980. Palynology of the plantbearing Rhaetian to Hettangian Kap Stewart Formation, Scoresby Sund, East Greenland. Review of Palaeobotany and Palynology 31:1-69.

Pedersen, K. R., P. R. Crane, and E. M. Friis. 1989. Pollen organs and seeds with Eucommiidites pollen. Grana 28:279-294.
Pellmyr, O., W. Tang, I. Groth, G. Bergsröm, and L. B. Thien. 1991. Cycad cone and angiosperm floral volatiles: inferences for the evolution of insect pollination. Biochemical Systematics and Ecology 19:623-627.

Picket, S. T. A., and M. L. Cadenasso. 2005. Vegetation dynamics. Pp. 172-198 in E. van der Maarel, ed. Vegetation ecology. Blackwell, Oxford.

Pohjamo, M., S. Laaka-Lindberg, O. Ovaskainen, and H. Korpelainen. 2006. Dispersal potential of spores and asexual propagules in the epixylic hepatic Anastrophyllum hellerianum. Evolutionary Ecology 20:415-430.

Powell, J. H. 2010. Jurassic sedimentation in the Cleveland Basin: a review. Proceedings of the Yorkshire Geological Society 58:21-72.

Prentice, I. C. 1985. Pollen representation, source area, and basin size: toward a unified theory of pollen analysis. Quaternary Research 23:76-86.

Pšenička, J., and S. Opluštil. 2013. The epiphytic plants in the fossil record and its example from in situ tuff from Pennsylvanian of Radnice Basin (Czech Republic). Bulletin of Geosciences 88:401-416.

R Development Core Team. 2014. R: A language and environment for statistical computing. R Foundation for Statistical Computing, version 3.1.2, Vienna, Austria. http:/ /www.R-project.org/.

Rawson, P. F., and J. K. Wright. 2000. Geologists' association guide No. 34. The Yorkshire coast. The Geologists' Association Guide, London.

Regal, P. J. 1982. Pollination by wind and animals: ecology of geographic patterns. Annual Review of Ecology and Systematics 13:497-524

Ren, D., C. C. Labandeira, J. A. Santiago-Blay, A. Rasnitsyn, C. Shih, A. Bashkuev, M. A. V. Logan, C. L. Hotton, and D. Dilcher. 2009. A probable pollination mode before angiosperms: Eurasian, long-proboscid scorpionflies. Science 326:840-847.

Riding, J. B. 1984. A palynological investigation of Toarcian to early Aalenian strata from the Blea Wyke area, Ravenscar, North Yorkshire. Proceedings of the Yorkshire Geological Society 45:109-122.

Riding, J. B., and J. K. Wright. 1989. Palynostratigraphy of the Scalby Formation (Middle Jurassic) of the Cleveland Basin, north-east Yorkshire. Proceedings of the Yorkshire Geological Society 47:349-354.

Romano, M., and M. A. Whyte. 2003. Jurassic dinosaur tracks and trackways of the Cleveland Basin, Yorkshire: preservation, diversity and distribution. Proceedings of the Yorkshire Geological Society 54:185-215

Romano, M., M. A. Whyte, and P. L. Manning. 1999. New sauropod dinosaur prints from the Saltwick Formation (Middle Jurassic) of the Cleveland Basin, Yorkshire. Proceedings of the Yorkshire Geological Society 52:361-369.

Roncaglia, L. 2004. Palynofacies analysis and organic-walled dinoflagellate cysts as indicators of palaeo-hydrographic changes: an example from Holocene sediments in Skálafjord, Faroe Islands. Marine Micropaleontology 50:21-42.

Scheihing, M. H. 1980. Reduction of wind velocity by the forest canopy and the rarity of non-arborescent plants in the Upper Carboniferous fossil record. Argumenta Palaeobotanica 6: 133-138.

Schneider, H., and P. Kenrick. 2001. An Early Cretaceous rootclimbing epiphyte (Lindsaeaceae) and its significance for calibrating the diversification of polypodiaceous ferns. Review of Palaeobotany and Palynology 115:33-41.

Schuettpelz, E., and K. M. Pryer. 2007. Fern phylogeny from 400 leptosporangiate species. Taxon 56:1037-1050.

- 2009. Evidence for a Cenozoic radiation of ferns in an angiosperm-dominated canopy. Proceedings of the National Academy of Sciences of the United States of America 106: 11200-11205. 
Schweitzer, H. J., J. H. A. van Konijnenburg-van Cittert, and J. van der Burgh. 1997. The Rhaeto-Jurassic flora of Iran and Afghanistan. 10. Bryophyta, Lycophyta, Sphenophyta, Pterophytaeusporangiate and -protoleptosporangiate. Palaeontographica Abteilung B 243:103-192.

Schwendemann, A. B., G. Wang, M. L. Mertz, R. T. McWilliams, S. L. Thatcher, and J. M. Osborn. 2007. Aerodynamics of saccate pollen and its implications for wind pollination. American Journal of Botany 94:1371-1381.

Skog, J. E., and C. R. Hill. 1992. The Mesozoic herbaceous lycopsids. Annals of the Missouri Botanical Garden 79:648-675.

Slater, S. M., W. A. Taylor, D. J. Batten, C. R. Hill, and C. H. Wellman. 2015. Morphology and wall ultrastructure of a new and highly distinctive megaspore from the Middle Jurassic of Yorkshire, UK. Review of Palaeobotany and Palynology 216:33-43.

Spicer, R. A., and C. R. Hill. 1979. Principal components and correspondence analyses of quantitative data from a Jurassic plant bed. Review of Palaeobotany and Palynology 28: 273-299.

Srivastava, S. K. 2011. Spore-pollen biostratigraphy of the English Jurassic. Palaeontographica Abteilung B 285:113-201.

Stukins, S., D. W. Jolley, D. Mcllroy, and A. J. Hartley. 2013. Middle Jurassic vegetation dynamics from allochthonous palynological assemblages: an example from a marginal marine depositional setting; Lajas Formation, Neuquén Basin, Argentina. Palaeogeography, Palaeoclimatology, Palaeoecology 392:117-127.

Tang, W. 1987. Insect pollination in the cycad Zamia pumila (Zamiaceae). American Journal of Botany 74:90-99.

ter Braak, C. J. F. 1995. Ordination. Pp. 91-173 in R. H. G. Jongman, C. J. F. ter Braak, and O. F. R. van Tongeren, eds. Data analysis in community and landscape ecology. Cambridge University Press, Cambridge.

Terry, I., G. H. Walter, C. Moore, R. Roemer, and C. Hull. 2007. Odor-mediated push-pull pollination in cycads. Science 318:70.

Tinner, W., B. Ammann, and P. Germann. 1996. Treeline fluctuations recorded for 12,500 years by soil profiles, pollen, and plant macrofossils in the central Swiss Alps. Arctic and Alpine Research 28:131-147.

Traverse, A. 2007. Paleopalynology, second edition. Springer, Netherlands.

Tstutsumi, C., and M. Kato. 2006. Evolution of epiphytes in Davalliaceae and related ferns. Botanical Journal of the Linnean Society 151:495-510.

Tyson, R. V. 1995. Sedimentary organic matter. Organic facies and palynofacies. Chapman and Hall, London.

Van der Zwan, C. J. 1990. Palynostratigraphy and palynofacies reconstruction of the Upper Jurassic to lowermost Cretaceous of the Draugen Field, offshore mid Norway. Review of Palaeobotany and Palynology 62:157-186.

van Konijnenburg-van Cittert, J. H. A. 1968. Androstrobus major, a new male cycad cone from the Jurassic of Yorkshire (England). Review of Palaeobotany and Palynology 7:267-273.

— . 1971. In situ gymnosperm pollen from the Middle Jurassic of Yorkshire. Acta Botanica Neerlandica 20:1-96.

—. 1972. Some additional notes on male gymnosperm fructifications from the Jurassic flora of Yorkshire. Acta Botanica Neerlandica 21:95-98.

- 1975. Some notes on Marattia anglica from the Jurassic of Yorkshire. Review of Palaeobotany and Palynology 20: 205-214.

- 1978. Osmundaceous spores in situ from the Jurassic of Yorkshire, England. Review of Palaeobotany and Palynology 26:125-141.
1981. Schizaeaceous spores in situ from the Jurassic of Yorkshire, England. Review of Palaeobotany and Palynology 33:169-181.

—. 1989. Dicksoniaceous spores in situ from the Jurassic of Yorkshire, England. Review of Palaeobotany and Palynology 61:273-301.

- 1993. A review of the Matoniaceae based on in situ spores. Review of Palaeobotany and Palynology 78:235-267.

- 1996. Two Osmundopsis species and their sterile foliage from the Middle Jurassic of Yorkshire. Palaeontology 39:719-731.

- 2000. Osmundaceous spores throughout time. Pp. 435-449 in M. M. Harley, C. M. Morton, and S. Blackmore, eds. Pollen and spores: morphology and biology. Royal Botanic Gardens, Kew.

—. 2008. The Jurassic fossil plant record of the UK area. Proceedings of the Geologists' Association 119:59-72.

—. 2010. The Early Jurassic male ginkgoalean inflorescence Stachyopitys preslii Schenk and its in situ pollen. Scripta Geologica Special Issue 7, 141-149.

van Konijnenburg-van Cittert, J. H. A., and H. S. Morgans. 1999. The Jurassic flora of Yorkshire. The Palaeontological Association, London.

van Konijnenburg-van Cittert, J. H. A., and J. van der Burgh. 1989. The flora from the Kimmeridgian (Upper Jurassic) of Culgower, Sutherland, Scotland. Review of Palaeobotany and Palynology 61:1-51.

Whitehead, D. R. 1983. Wind pollination: some ecological and evolutionary perspectives. Pp. 97-108 in L. Real, ed. Pollination biology. Academic Press, New York, USA.

Whyte, M. A., and M. Romano. 1993. Footprints of a sauropod dinosaur from the Middle Jurassic of Yorkshire. Proceedings of the Geologists' Association 104:195-199.

- 2001a. A dinosaur ichnocoenosis from the Middle Jurassic of Yorkshire, UK. Ichnos 8:223-234.

—. 2001b. Probable stegosaurian dinosaur tracks from the Saltwick Formation (Middle Jurassic) of Yorkshire. England. Proceedings of the Geologists' Association 112:45-54.

Whyte, M. A., M. Romano, J. G. Hudson, and W. Watts. 2006. Discovery of the largest theropod dinosaur track known from the Middle Jurassic of Yorkshire. Proceedings of the Yorkshire Geological Society 56:77-80.

Whyte, M. A., M. Romano, and D. J. Elvidge. 2007. Reconstruction of Middle Jurassic dinosaur-dominated communities from the vertebrate ichnofauna of the Cleveland Basin of Yorkshire, UK. Ichnos 14:117-129.

Whyte, M. A., M. Romano, and W. Watts. 2010. Yorkshire dinosaurs: a history in two parts. Geological Society, London, Special Publications 343:189-207.

Wilson, G. A. 2002. Insect pollination in the cycad genus Bowenia Hook. ex Hook. f. (Stangeriaceae). Biotropica 34: 438-441.

Wing, S. L., and G. J. Harrington. 2001. Floral response to rapid warming in the earliest Eocene and implications for concurrent faunal change. Paleobiology 27:539-563.

Yang, X. J., E. M. Friis, and Z. Y. Zhou. 2008. Ovule-bearing organs of Ginkgo ginkgoidea (Tralau) comb. nov., and associated leaves from the Middle Jurassic of Scania, South Sweden. Review of Palaeobotany and Palynology 149:1-17.

Young, G. M., and J. Bird. 1822. A geological survey of the Yorkshire coast: describing the strata and fossils occurring between the Humber and the Tees, from the Germany Ocean to the plain of York. R. Kirby, Whitby.

Ziaja, J. 2006. Lower Jurassic spores and pollen grains from Odrowąż, Mesozoic margin of the Holy Cross Mountains, Poland. Acta Palaeobotanica 46:3-83. 